\title{
舌神経切断後の舌粘膜の変化に関する実験的研究
}

\author{
九州蒾科大学大学院菌学研究科口腔外科学第 1 専攻（指導：山田長敬教授）
}

藤本誠 一

昭和 60 年 12 月 2 日受付

\section{An Experimental Study of Change in Lingual Body Mucosa after Transection of the Lingual Nerve}

\author{
Seiichi Fujimoto \\ First Department of Oral Surgery (Director: Prof. Nagayoshi Yamada) \\ Kyushu Dental College, Kitakyushu, Japan
}

In daily clinical practice, dysqeusia patients having lingual abnormal findings are frequently encounted. However, most of studies were aimed at the taste buds and that controlling nerve. Therefore, with a purpose to investigate roles of the lingual body mucosa, especially the form of the lingual papillae and their functional maintenance, the author transected the unilateral lingual nerve of rats, and scanning electron microscopic and histopathological examinations were made of the changes in the anterior region of the tongue.

The results were as follows:

1. Bending of the lingual tip region to the non-transected side was noted in a rat 24 hours after the transection of the lingual nerve, and since then bending accompanied by atrophy of the tongue musculature was very frequently observed until the 21 st day after the transection.

2. From 3rd day after the transection, the filiform papillar arrangement became irregular and ulcerous changes accompanied by the defective lingual papillae were noted in the lingual tip or marginal region. The changes were continued until the 14 th day after the transection were no longer noted on the days thereafter.

3. From 3rd day after the transection, the taste buds of the fungiform papillae began to show degenerative findings and the taste bud-composing cells decreased markedly in number.

4. On 7 th day after the transection, all the taste buds were completely degenerated and disappeared and were displaced by surrounding epithelial cells. Observation by SEM revealed strong atrophy in the fungiform papillae and difficulty in discriminating the fungiform papillae.

5. On 21st day after the transection, regenerated taste buds were observed in the epithelial layer of the fungiform papillae. The taste pores were insufficiently developed and their communication with outside was not yet observed. All the cases 
showed opening of the taste pores since the 35th day after transection of the lingual nerve.

6. Degeneration and regeneration, caused by transection of the lingual nerve, of the fungiform papillae and their taste buds distributed the lingual tip and around medial groove in the lingual body were not necessarily limited to the transected side but extended to some of the non-transected side as well. Also, in the transected side, papillae presenting normal findings without being affected were observed.

The above results suggest that the lingual nerve was very importantly associated not only with sense, regeneration and differentiation of the taste buds but also with functional maintenance of the lingual body mucosa, and that it was involved somehow in movement of musculature of the lingual tip region.

Key words : Denervation /Reinnervation /Lingual nerve/SEM/Rat/Lingual body mucosa

\section{緒言}

口腔外科領域において，外傷時や手術時に神経を損傷 もしくは切断することは臨床的に多々遭遇するところで ある，乙の場合，神経支配領域下の諸器官が運動，知 覚，味覚など種々の機能障害を䓯起するてとは当然のて とで，外科処置にあたっっては常にその保護ならびに対策 が考慮されて抢り，種々な立場から神経切断に関する研 究が行なわれている。

哺乳類や魚類などの各種舌乳頭味蕾ではその形態や機 能を維持するため味覚神経の存在が必要であり，味覚神 経が失われると味蕾は変性消失し, 味覚神経が再生す ると味蕾も再生することが実験的に証明されている。 Olmsted (1920) ${ }^{1}$ が Ameiurus nebulosus を用いて 味蕾の変性・再生とその支配神経の関係について報告し

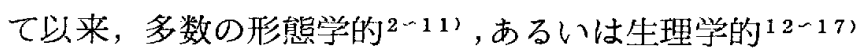
報告がなされている。

味蕾の構造や機能を維持させる働きは，神経の trophic な働きによるものであるとされている121，Guth (1969) ${ }^{18)}$ は味蕾の構造や機能維持のほかに，筋線維を 構造的, 機能的に維持させる働きなども trophic function によるものであると述心゙ている. 日常臨床におい ても，味覚障害患者に明らかに舌の異常所見を認める症 例に遭遇する。しかしながら，舌粘膜，特に舌乳頭の形 態とその機能維持に関する詳細な㖄究は少なく，わずか に Mizuno ら (1973) ${ }^{191}$ と石井 (1979) 201 がそれぞれ ネコとヒトの舌支配神経を切断し, 舌粘膜の変化につい て報告しているにすぎない．

そこで著者は, 舌神経の舌粘膜, 特に舌乳頭の形態と
その機能維持に対する役割を追求するため, ラット片側 舌神経を切断し, 舌前方部の変化, 動態を走查電子顕微 鏡 (SEM) 的に検討すると同時に，病理組織学的に味 蕾の変性・再生について検索し, 興味深い知見を得たの で報告する。

\section{実験動物ならびに実験方法}

\section{1. 実験動物}

実験動物には, 生後60日, 体重200〜250gの雄 Wistar 系ラット88匹を用いた。全動物はオリエンタル社製固型 飼料 $(\mathrm{FM})$ にて，同一条件下で飼育した。

2. 実験方法

$3 \%$ 抱水クロラール 水溶液 $(10 \mathrm{cc} / \mathrm{kg})$ をラット腹腔 内に注射し，仰臥位に固定後，正中線沿ってオトガイ 下部から舌悬部にかけ約 $5 \mathrm{~cm}$ の皮膚切開を行なった。 次に広頸筋を外方に娳離し，顎二腹筋前腹の起始部を切 離した， その後，咬筋と顎二腹筇前腹との間を鈍的に剥 離し, 手術用顕微鏡 (KONAN K-880 MFW 対向型) 下で右側舌神経を露出させた。露出した舌神経を微小外 科用器具を用いて周囲組織から注意樑く剶離し, 鼓索神 释と交通する部より末梢側（顎下神経節と交通する部よ り中枢側)で切断した。この結果，両断端は収縮し約 $1 \mathrm{~mm}$ の間陌を生じたが，特別な操作は施さずそのまま 切断創上を閉鎖した。動物は神経切断後， 1，3，5，7， $10 ， 14 ， 21 ， 28 ， 35 ， 40 ， 60 ， 90 ， 120$ 日の各期閒にわ たって飼育した。なお，左側舌神経は何ら外科的侵襲を 加えずコントロールとした。

3. 試料作製

動物を各期間飼育した後，抱水クロラール麻酔下に 
て左心室より生理食塩水にて前灌流し把液を洗い出した 後, $2.5 \%$ グルタールアルデヒド溶液（カコジル酸緩衝 液 $\mathrm{pH}$ 7.4）にて灌流固定を行なった。灌流固定後直ち に舌全体を摘出し, 舌体部と舌根部に二分し前記固定液 にて再固定を行なった. 再固定後, 通法に従いアルコー 儿系列にて脱水し, 臨界点乾燥 (日立 $\mathrm{HCP}-2$ 型), 白 金蒸着（JFC-1100）を施し, SEM（日本電子 $T-20$, T-300) 観察を行なった。一方, 光学顕微鏡（光顕） 標本（一部 SEM 観察後の試料も含む）は通法に従いパ ラフィン包埋し， $5 \mu \mathrm{m}$ の連続切片標本を作製，へマト キシリン・エオジン重染色抢よびアザン染色 (Cason's method）を施し鏡検した。また，実験群における茸状 乳頭の味孔の確認を目的とし，一部の試料について味孔 染色法（1\% Ponceau S $)^{21)}$ を施した。

\section{実 験 成 績}

\section{1. 正常所見}

1）舌背面の肉眼的所見

舌は細長く，臼崡に相当する部分では両側より圧排さ れたように幅が狄くなっている．臼歯より後方部は幅が やや広くなっている，なお，観察を容易にするため，舌 全体を舌前方部（舌前方約 $1 / 3$ ), 舌中央部（舌中央約 $1 / 3$ ) および舌後方部（舌後方約 $1 / 3$ ) に分けて記述する（Fig. 1).

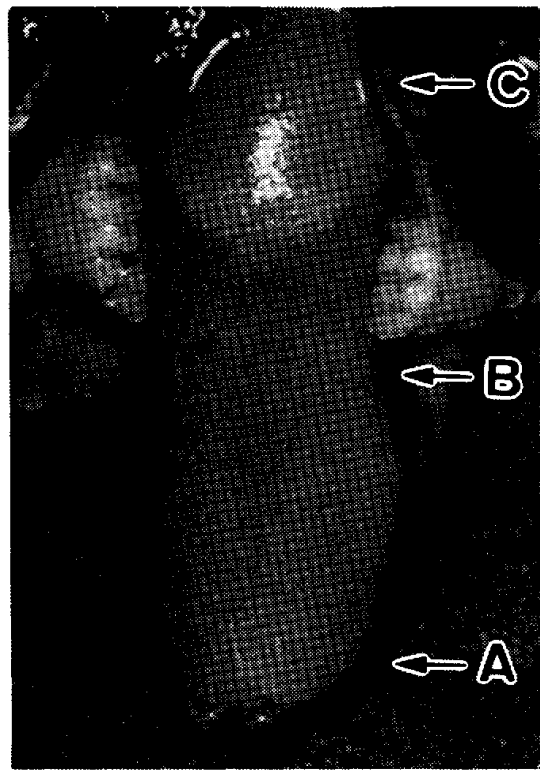

Fig. 1 ラット舌背面観
$A ：$ 舌前方部（舌前方約 $1 / 3$ )
B : 舌中央部 (舌中央約 $1 / 3$ )
$\mathrm{C}:$ 舌後方部 (舌後方約 $1 / 3$ )

舌前方部には正中に舌正中溝に相当する深い溝が観察 されるが，舌中央部には及んでいない。

舌中央部之舌後方部との境界付近には舌体部と比較 し，やや白みを帯びた隆起が喼められる．乙の部分がい わゆる霜間隆起 (intermolar eminence) である。こ の隆起は舌体部とは明暸に境されるが, 後方では明らか な境界なしに次第に口峡部へと自然移行している。

2）舌乳頭の SEM およよび光顕龍見

\section{a. SEM 所見}

部位によって若干形態の異なった系状乳頭が舌背全面 に密生している. 舌前方部に分布する糸状乳頭は，前後 方向に重なりあう先端が丸い扁平な突起（上端）部をも っている．その基底部は厚い上皮細胞で取り囲まれてい て，上皮鞘を形成している。乙の乳頭は全般的に乫起部 先端を後方に傾斜させているが（Fig．2），舌尖部では

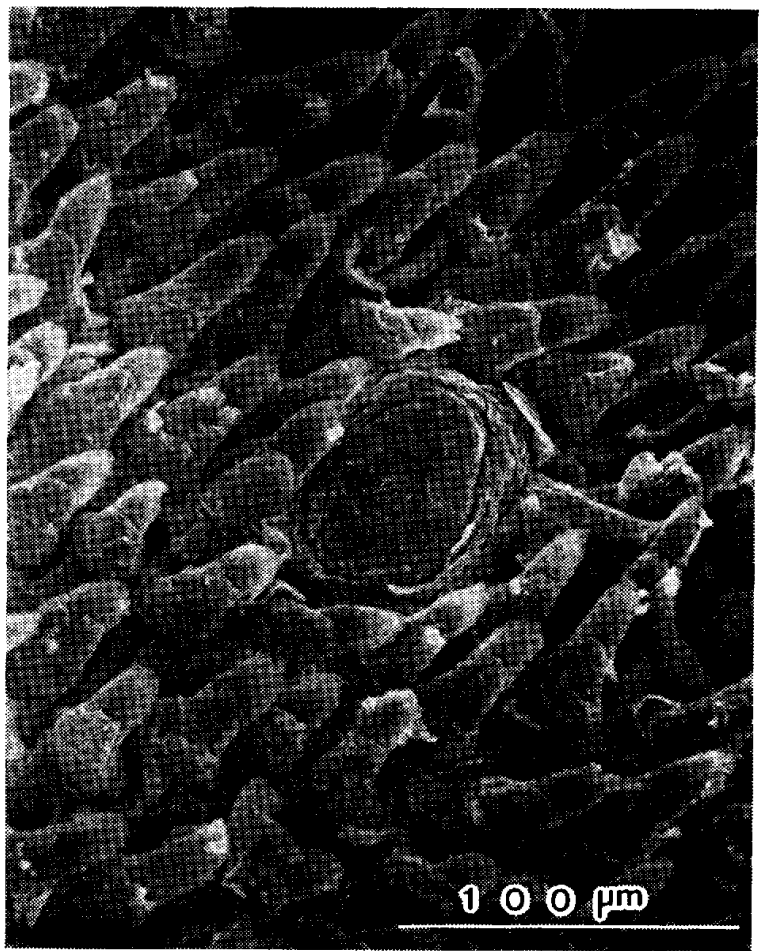

Fig. 2 正常な糸状乳頭と茸状乳頭の SEM 像

前方に，側縁部で後外側に，正中寄りの部で後内側に向 けている。乙れら系状乳頭の配列状態は, 舌正中溝に相 当する深い拲を境に左右対称となっている.

咠状乳頭は系状乳頭間に散在し，舌前方部，特に舌尖 部に多く分布し, 後方にゆくに従って著しく減少する. 数および配列状態は必ずしも左右対称ではない，本乳頭 は, 径 100〜150 $\mathrm{m}$ の帯円形を呈しており, 乳頭背面は 軽く圧平され，辺縁は扁平上皮が積み重ねられた凰状構 造を呈している，乳頭中央部には，径 $2 \sim 3 \mu \mathrm{m}$ の臍状 


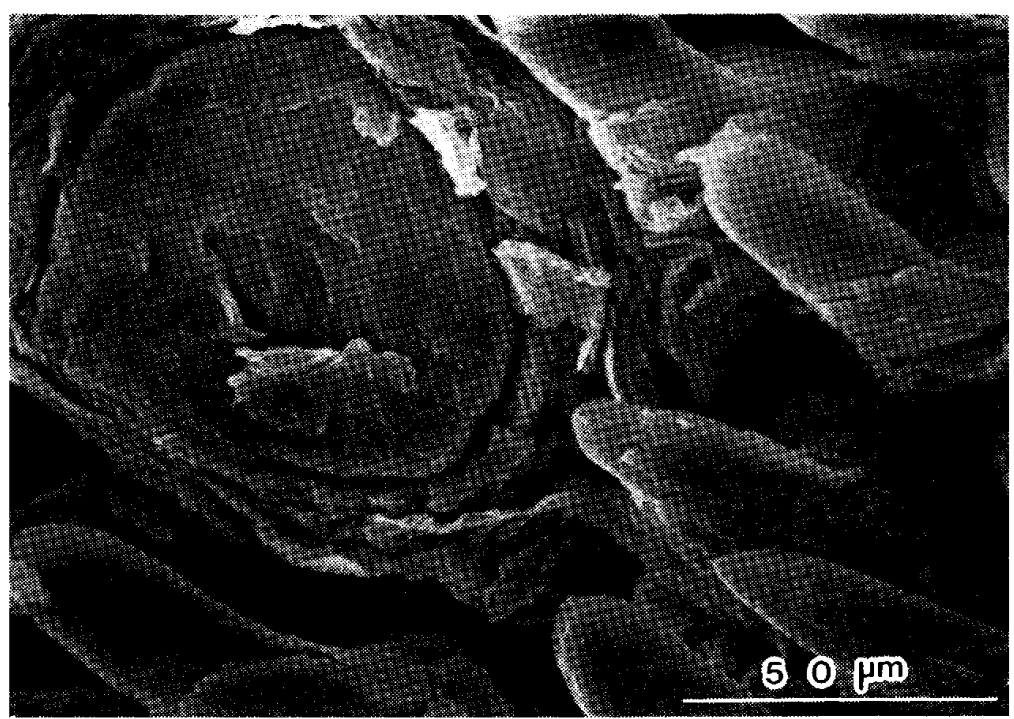

Fig. 3 正常な苗状乳頭の SEM 像

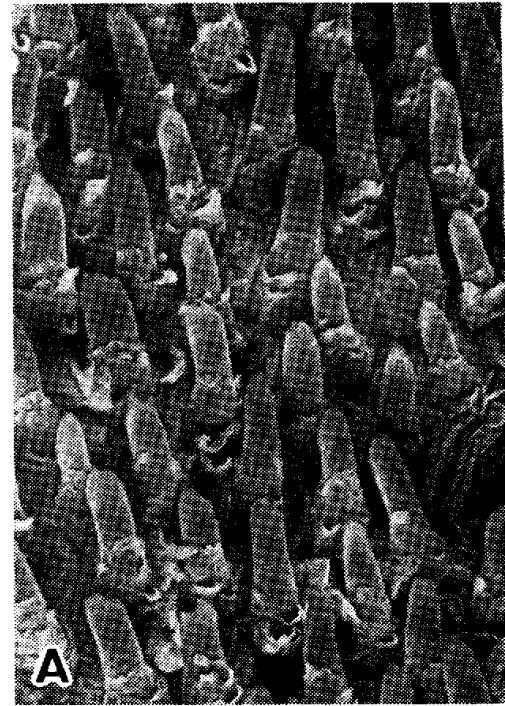

Fig. 4
切断 1 日目 $\mathrm{A}$ : 非切断側

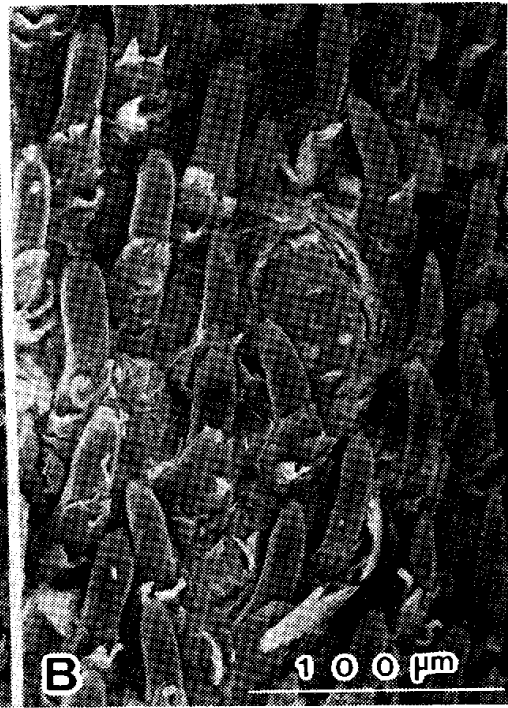

SEM 像

B : 切断 側
ないし噴火口状をなす味孔を通常 1 個有し，その外周の 上皮が堤防状にもり上っている(Fig．3）。

b. 光顕所見

糸状乳頭の側面像としては, 凸面は前方に, 凹面は後 方に面して抢り，乳頭と乳頭の間には豊富な乳頭間粘膜 上皮が認められる。乙れら各部の上皮の角化度は後面部 で最も強く，次いで前面部，そして乳頭閒上皮部の順で 弱くなっている。

苜状乳頭は，広い背面部とやや㹨くなった基部からな る苜様の外観を是する，乳頭や乳頭外郭は比較的厚い上 皮にて被覆されて抢り，乳頭背面は一般的に平坦であ る．その最表㞒はエオジンに強染する角質首が均一な厚 さをなしている，乳頭背面上皮中央には，卵円形の味菅
が通常 1 個認められる。味蕾の大きさは，幅径 50〜60 $\mu \mathrm{m}$, 丈 $70 \sim 80 \mu \mathrm{m} て ゙$, 短い味管をもって口腔に開口して いる。味蕾構成細胞は，類円形にして明調な核を有す る細胞 (light cell) と, 細長く暗調な核を有する 細胞 (dark cell) とが明瞭に認められる.

\section{2 . 実験所見}

切断 1 日目

舌正中溝に相当する部分が Fig. 7 に示すように非切 断側に彎曲偏位し，かつ舌尖が軽く非切断側へ率引され たような状熊を呈するものが一例認められた。

SEM で舌前方部を観察してみると，系状乳頭の配列 状態は非切断側と変わりなく, 大部分のものは突起部先 端を後方に傾斜しており，また，舌尖のものは前方に， 


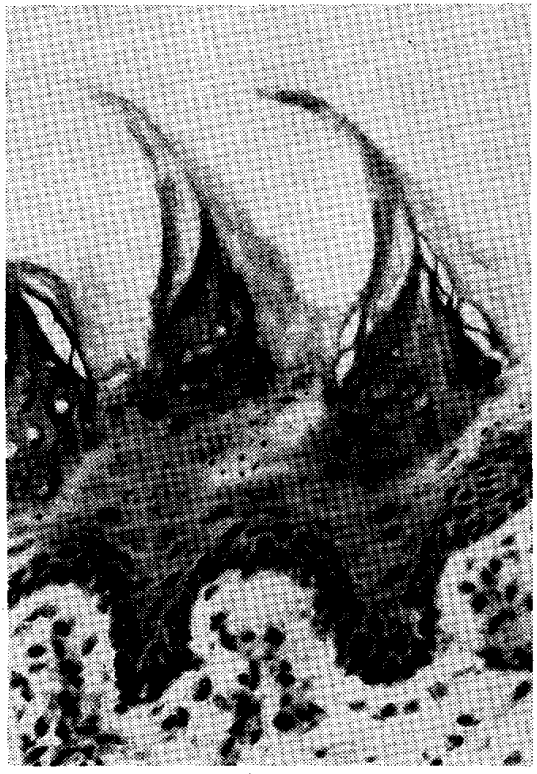

Fig. 5 切断 1 日目 糸状乳頭の断面像 $(\times 100)$ $\mathrm{H}-\mathrm{E}$ 染色

側縁部は後外側に，正中寄りは後内側に傾斜している。 また, 乳頭の形態をみても, 乳頭先端が比較的丸みを帯 びていて, 非切断側のものと変わりない. しかし, 舌尖 部の彎曲偏位が認められた例の切断側乳頭先端は幾分細 くなっている(Fig.4).

咠状乳頭に関しては, 非切断側のものと対比して形 態, 大きさ，数などに変化は認められない，味孔はすべ ての苜状乳頭に観察することができる．

光顕で観察しても, 糸状乳頭に著変は認められない。
乳頭間粘膜上皮層の基底細胞は立方形を呈し，表層に ゆくに従って細胞の大きさ, 形が変わり, 顆粒層に至っ てへマトキシリンに濃染する keratohyaline 顆粒が観 察される，表層の角質層はエオジンに浀染している，乳 頭前面部の基底紏胞も同じく立方形を呈し，顆粒層には keratohyaline 顆粒を認める。乙の部の角質風は他部 に比して愿い，乳頭後面部の基底細胞は紡鍾形に近い形 態をなし，表屠にゆくに従ってエオジンに濃染するよう になり，角質層へと移行する(Fig. 5).

舌中央部と側縁部にお活茸状乳頭の味蕾は幾分幅径 を減じているものの，構成細胞としての類円形を呈する 比較的大きな核を有する明調細胞や，ヘマトキシリンに 濃染する長紡鍾状を呈する暗調細胞がはっきりと観察さ れる (Fig. 6). 舌正中寄りに分布する咠状乳頭は，非

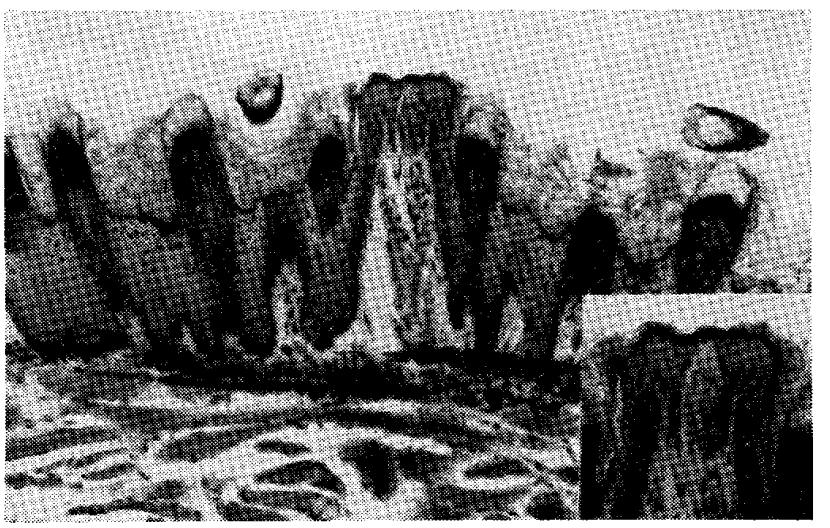

Fig. 6 切断 1 日目 茸状乳頭の断面像 $(\times 50)$ 上一部掋大 $(\times 100) \quad \mathrm{H}-\mathrm{E}$ 染色

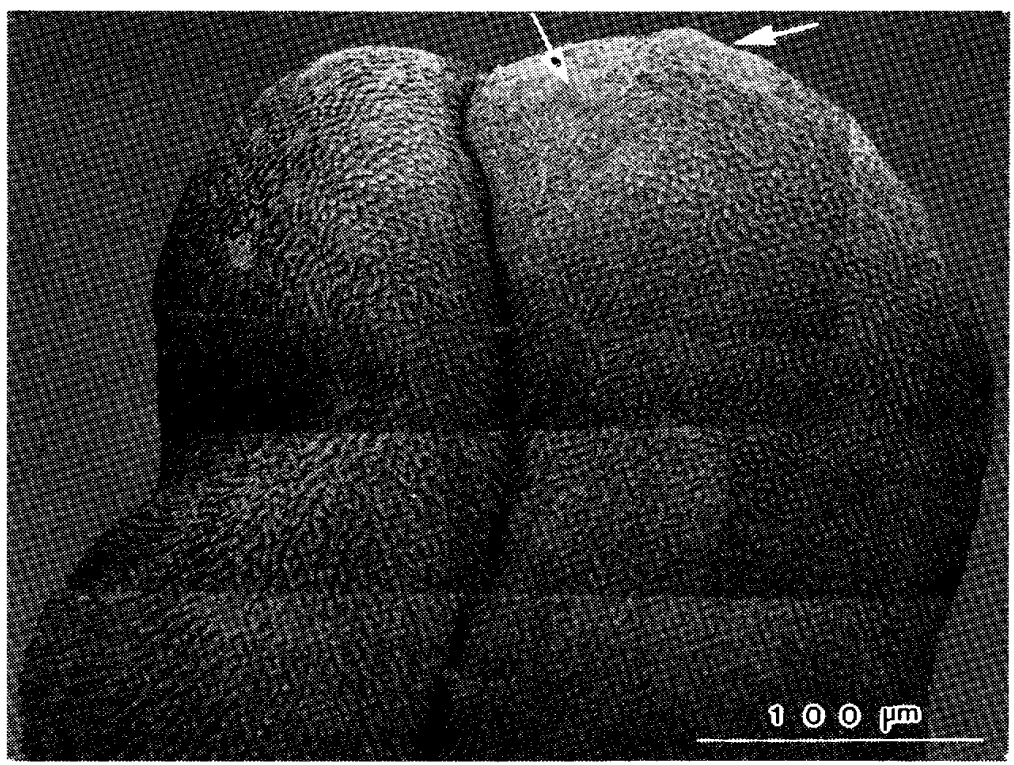

Fig. 7 切断 3 日目にみられる舌尖部の彎曲偏位 矢印：舌乳頭の欠如に伴う漬瘍形成部 


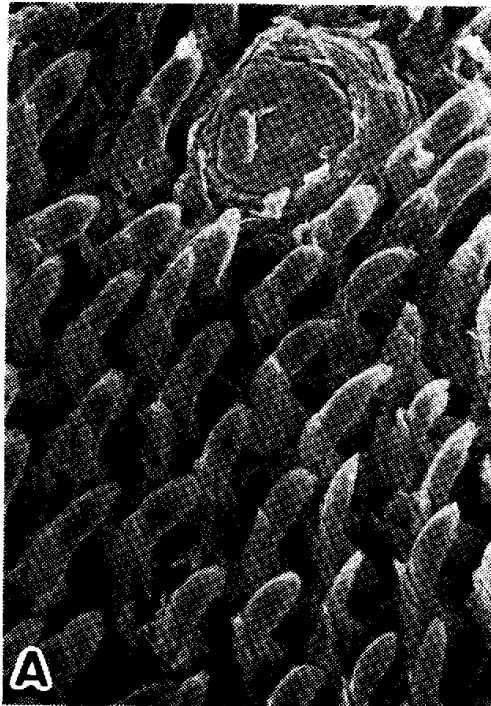

Fig. 8
切断 3 日目 A : 非切断 側

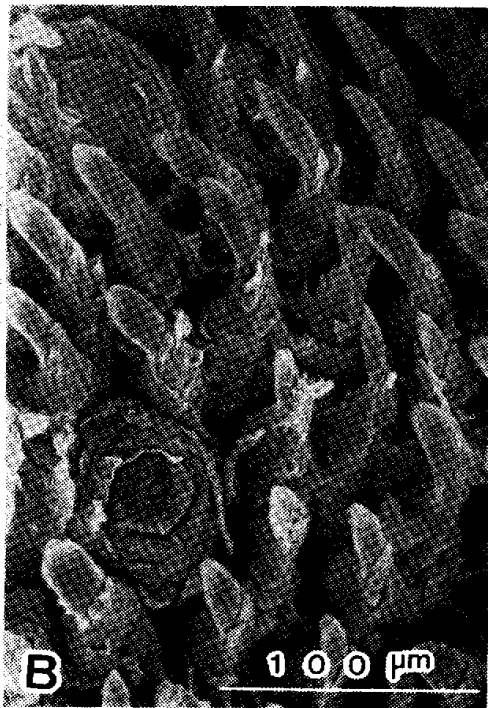

SEM 像

B：切断 側

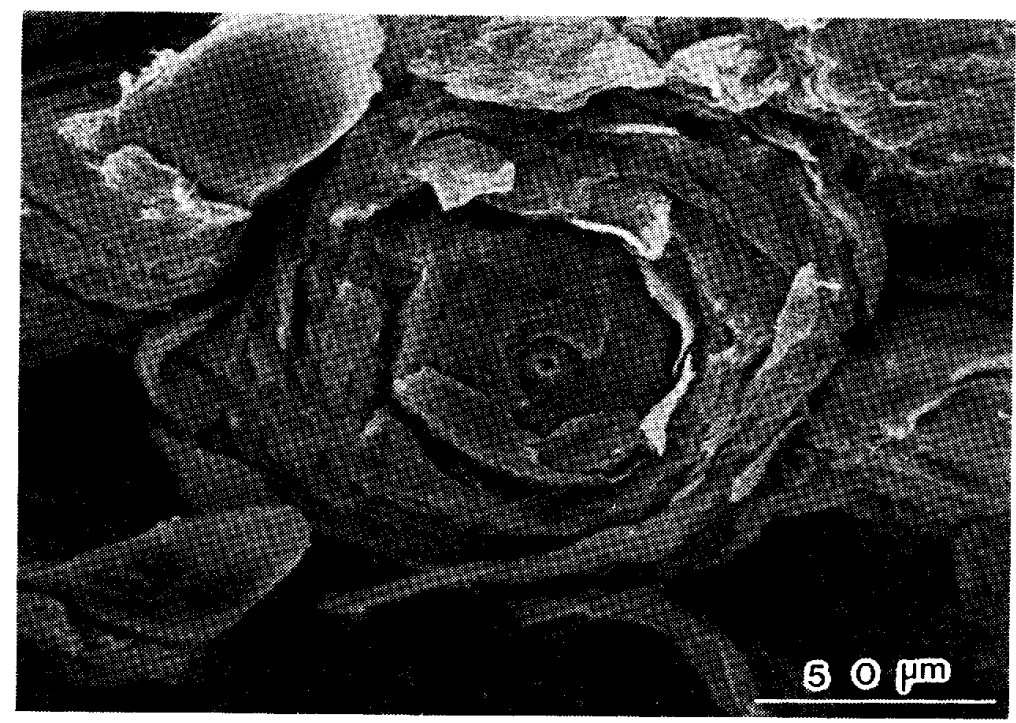

Fig. 9 切断 3 日目 菆状乳頭の SEM 像

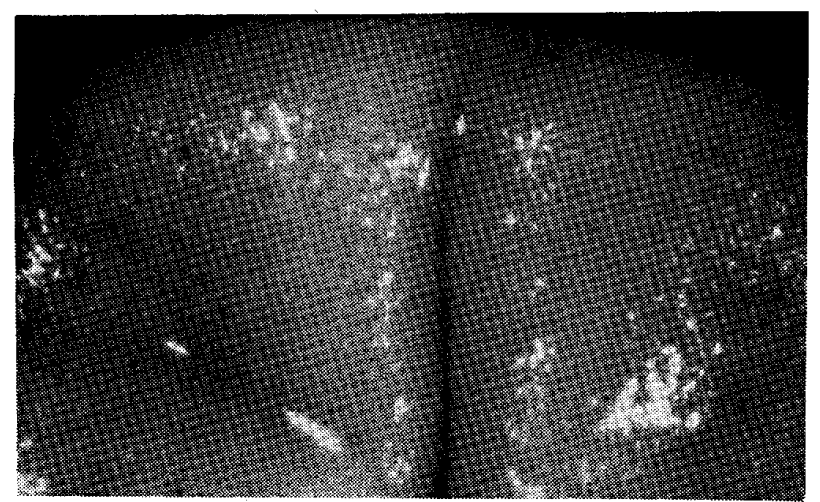

Fig. 10 切断 3 日目 実体顕微鏡像（×20） $1 \%$ Ponceau S
切断側のものと比べてもほとんど変化は認められない。 切断 3 日目

前期例にてみられた舌正中溝相当部の非切断側への彎 曲偏位が実験例数の半分に観察されるようになった。そ の場合の切断側舌尖部や側縁部に分布する系状乳頭と革 状乳頭の一部に欠如がみられ，その部に潰痬の形成が琶 められる (Fig - 7).

SEM で観察すると, 切断側舌尖部の糸状乳頭は配列 が不規則となり，かつ乳頭先端が先細りになっている。 また，乳頭基底部から乳頭間部にかけての上皮に肥愿が みられるとともに，部分的な上皮鞘の剥離が顕著になっ ている (Fig. 8). 


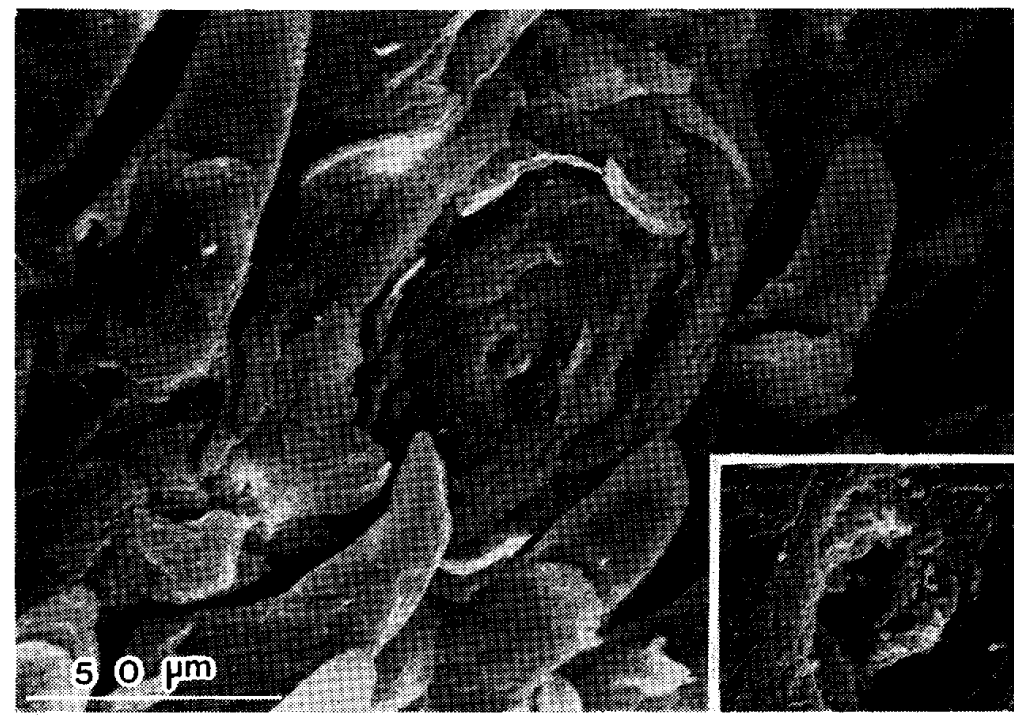

F1g. 11 切断 3 日目苜状乳頭の SEM 像と味孔部の拡大

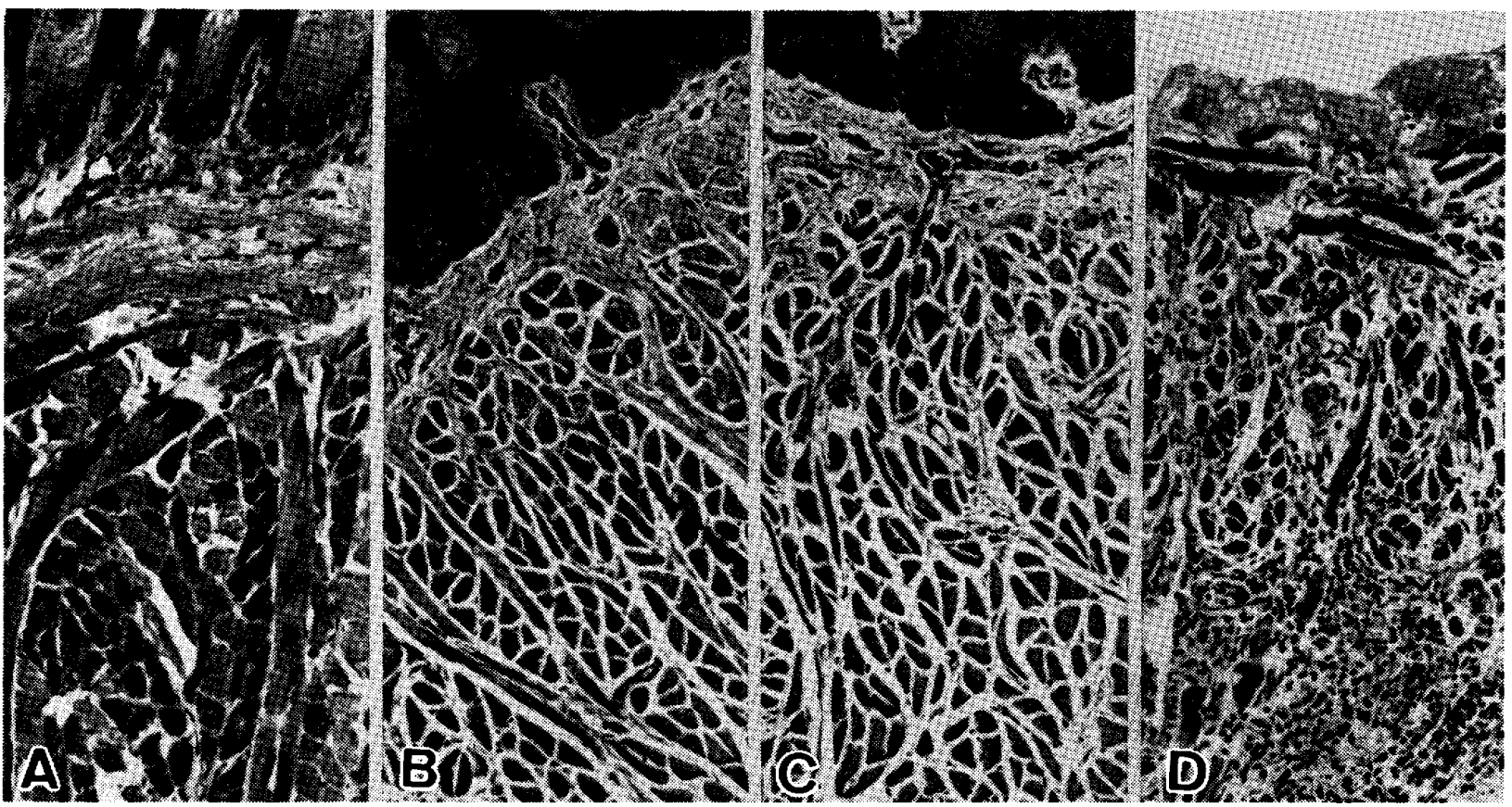

Fig. 12 切断 3 日目 舌筋の萎縮像 $(\times 50) \quad$ H-E 染色
A : 非切断側側縁部
B：非切断側正中寄り
$\mathrm{C}$ : 正中部
D：切断側側縁部（潰瘍部）

革状乳頭では，背面中央部に陷凹ができ，さらに背 面上皮と乳頭周壁上皮との間の溝が著明となっている。 すべての茸状乳頭背面には，味孔の開口が認められる (Fig. 9). $1 \%$ Ponceau S 液にて染色すると，Fig. 10 に示すように非切断側の味孔は明らかに Ponceau S に濃染するのに対し，切断側茸状乳頭の味孔部は色素に 全く無染の状熊である. また, 舌尖正中寄りにある乳頭
には, 昧管から味孔開口部にかけ棍棒状乫起を突出させ ているものも権察される (Fig . 11).

光顕で観察すると, 潰瘍部の上皮は完全に久如し，そ れに近い部分の上縦舌筋ならびに横舌筋の一部の筋線維 は高度な萎縮を呈している．その周りの筋線維束の配列 も不規則で，筋線維束間の結合組織は柾となり若干のり ンパ球浸潤と毛細血管の拡張が認められる。正中部にお 
いても，筋線維の萎縮像が非切断側まで及んでいるのが 認められるが，それ的ど顕著ではなく，等線維束の配列 も規則的でリンパ球の浸潤は認められない（Fig. 12）。 糸状乳頭の角質層より下方の上皮層は各部之も切断 1 日目と同様差異は認められないが，乳頭前面部之後面部 の角質層の副離が著明なものが多い（Fig.13）。茸状乳 頭の味蕾は萎縮し, 味蕾構成細胞, 特に明調細胞の数の 減少が著しく，それに応じて紼胞間隍が増大している.

切断 5 日目

切断 3 日目と同様，舌正中溝に相当する部が非切断側 に彎曲偏位し，かつ舌尖が非切断側に率引されているも のが 6 例中 4 例に羿められた。また，半数例に切断側舌

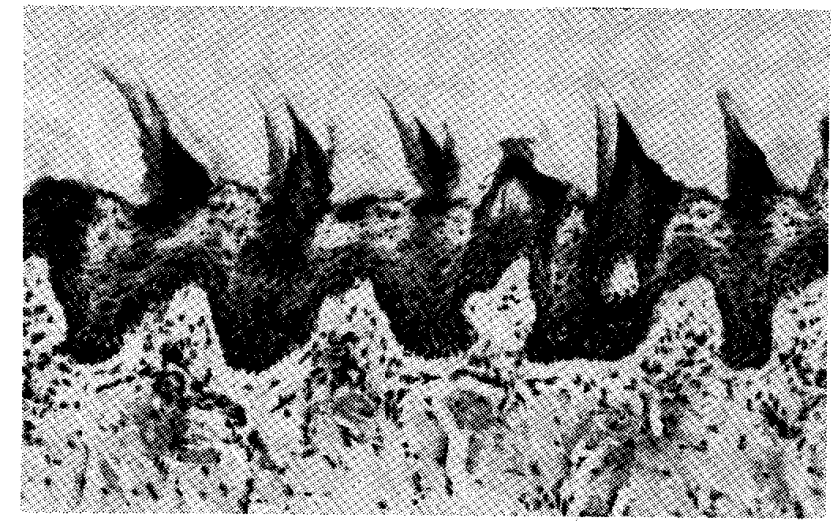

Fig. 13 切断 3 日目 采状乳頭の断面像 (×50) H-E 染色

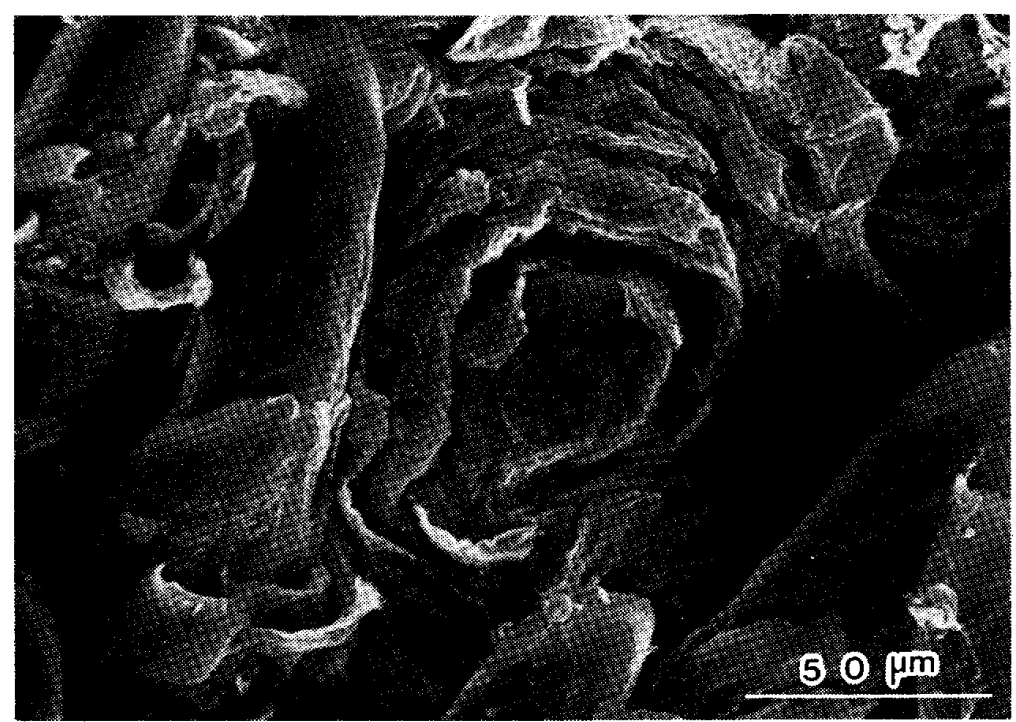

Fig. 14 切断 5 日目 茸状乳頭の SEM 像

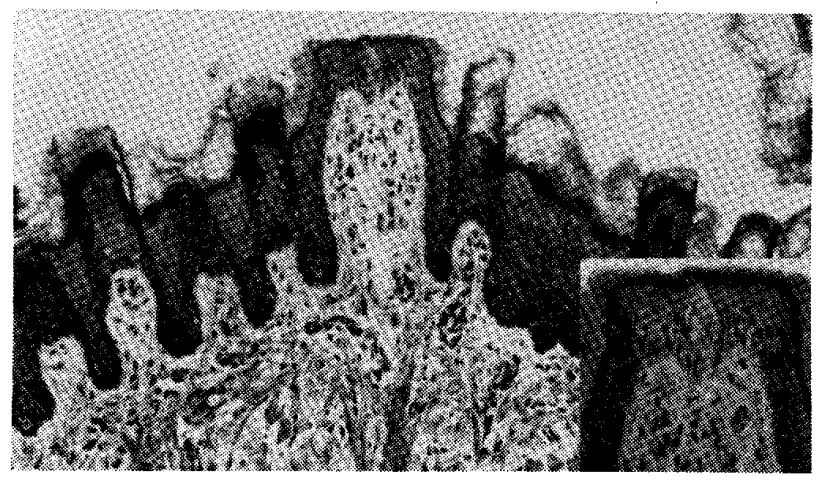

Fig. 15 切断 5 日目茸状乳頭の断面像（ $\times 50 ）$ と一部拡大 $(\times 100) \quad \mathrm{H}-\mathrm{E}$ 染色
SEM で観察すると, 糸状乳頭は切断 3 日目と同様, 配列は不規則となり, 特に舌尖部正中寄りには基底部上

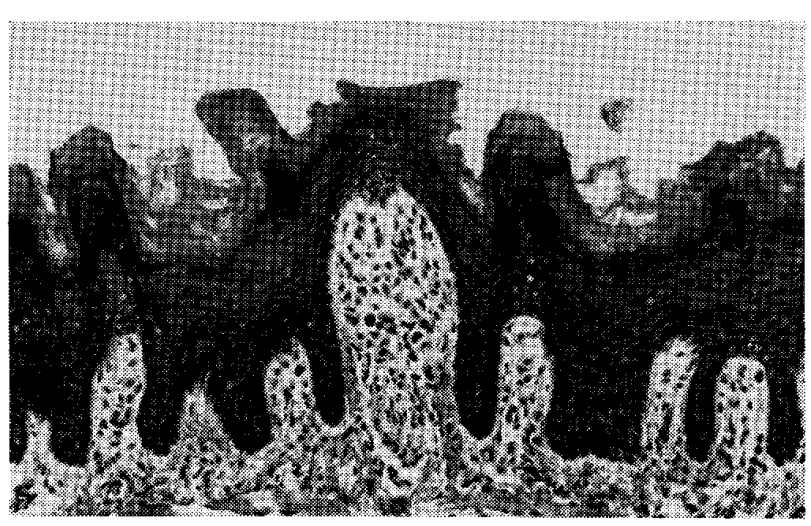

Fig. 16 切断 5 日目 聶状乳頭の断面像 $(\times 50)$ $\mathrm{H}-\mathrm{E}$ 染色
方から乳頭先端にかけ先細りになっているものが多く認 められる。

咠状乳頭では，萎縮傾向が強くなり，背面中央部の陷 


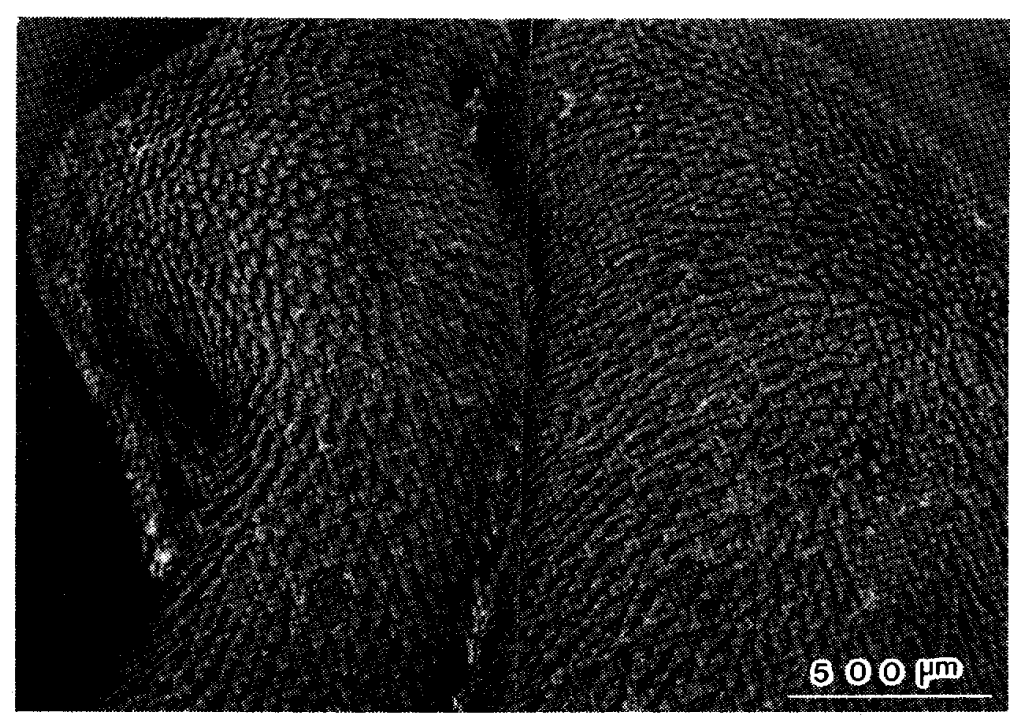

Fig. 17 切断 7 日目 SEM 像

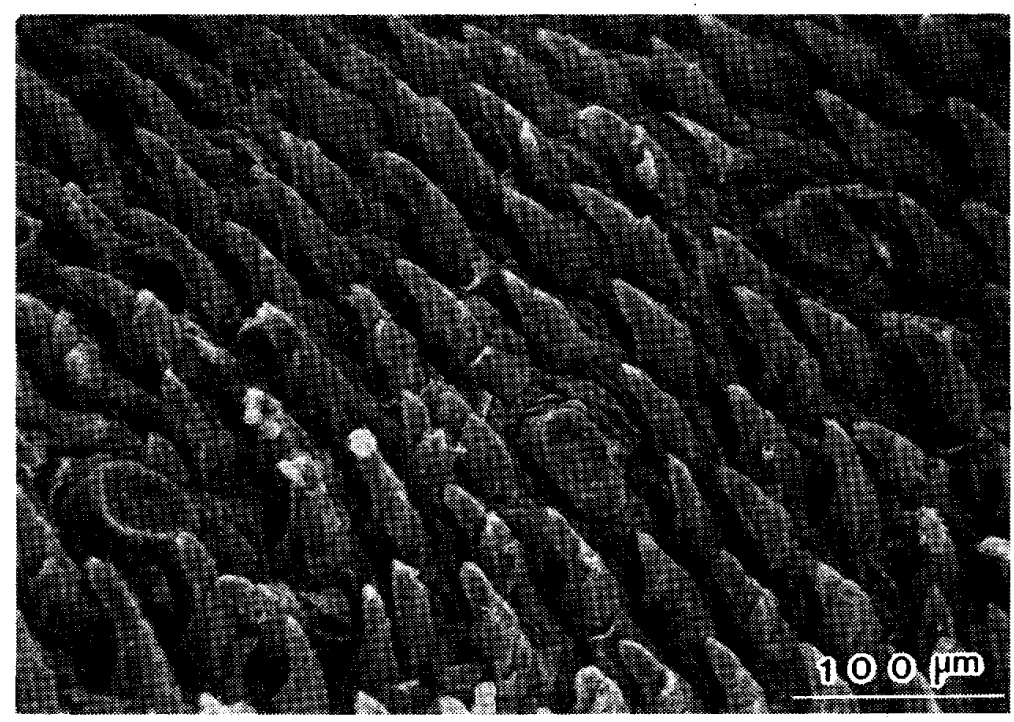

Fig. 18 切断 7 日目 系状乳頭之革状乳頭の SEM 像

凹と乳頭周壁上皮の剝離が著明となっている。味孔は本 来の形態を失って不規則な形状をしているため，開口 が認められるものと認められないものとが混在している (Fig. 14). 1\% Ponceau S 液にて染色すると，切 断側咠状乳頭の味孔部は色素に全く無染である.

光顕で観察すると, 筋線維の菱縮状態や糸状乳頭の角 質状態，さらに上皮の刹離状態は切断 3 日目とほとんぞ 同様な所見を呈している. 舌前方部の正中笴りの部分や 舌中央部に分布する咠状乳頭の味蕾は, 幅径, 丈とも減 少し, 味蕾本来の形態を失っている.味蕾内には変性菱 縮した細胞を少数認める（Fig．15）。一方，側縁部の苜 状乳頭は乳頭自体の縮小化が著しく，かつ角質層が肥厚 している，そのため味蕾はみられず，周辺の上皮細胞に
完全に置換されている（Fig．16）.

切断 7 日目

舌尖が非切断側へ強く彎曲偏位し，切断側舌尖部や側 縁部には部分的に潰瘍形成を呈するものが半数例に認め られた。中には, 丈が極端に短くなった糸状乳頭様の集 合体も認められる (Fig. 17).

SEM の観察では, 系状乳頭の配列は依然として不規 則であり，乳頭先端が尖鋭化したものが多くなってい る.さらに，乳頭基底部から隣接乳頭間部にかけての粘 膜上皮が肥厚気味になっているものもある.しかし, 乳頭 基底部の上皮剶離はそれはど著明ではない（Fig．18）。

茸状乳頭は，非切断側のものと明らかに異なった外観 を呈する.すなわち, 乳頭の圧平萎縮傾向が強いため, 
糸状乳頭よりも丈が極端に低く，また，乳頭背面中央部 はクレータ状に宿山し，乳頭周壁上皮や乳頭間粘膜上皮 に剝離が詡められるものが多くなっている，茸状乳頭
後方に彎曲している（Fig．20）。舌中央部および側縁部 における苜状乳頭は，角質層が肥厚して円鍾形に近い形 状を呈するものが多い，そのため，乳頭下部は著しく狭

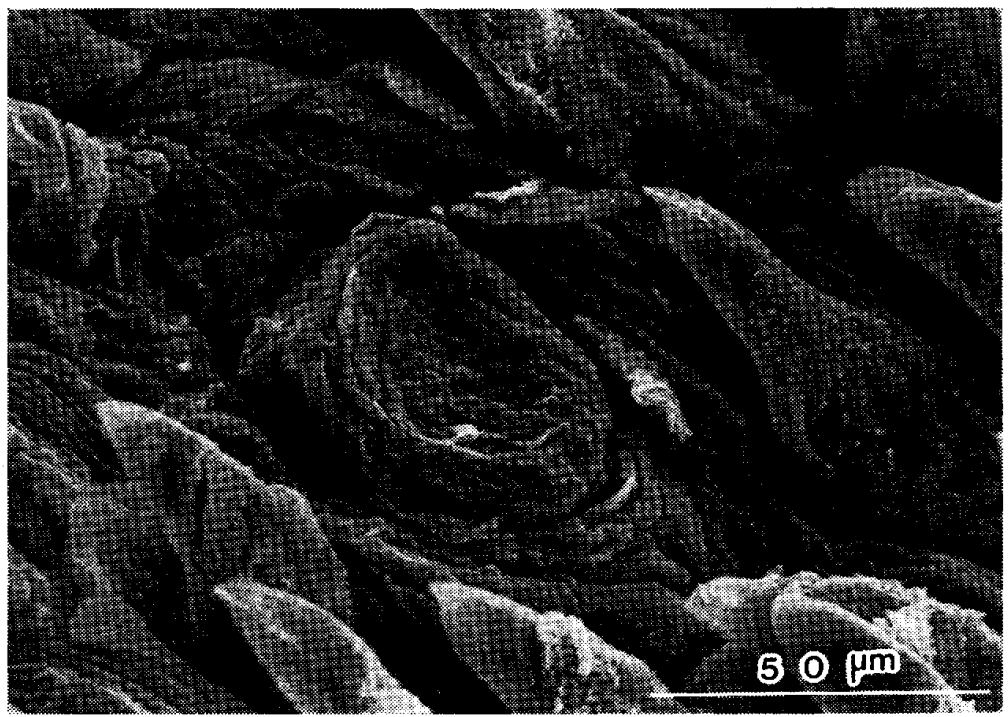

Fig. 19 切断 7 日目

咠状乳頭の SEM 像

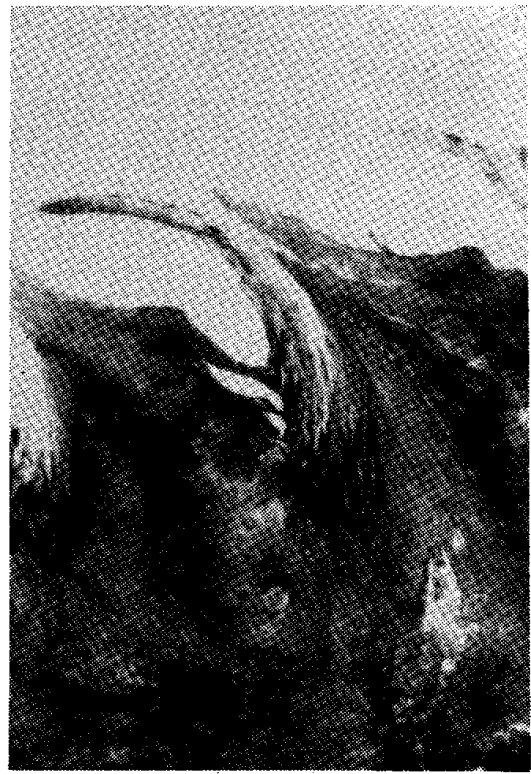

Fig. 20 切断 7 日目 䒺状乳頭の断面像 $(\times 100)$ アザン染色

の味孔は，す心゙て完全に屚平上皮にて閉塞されている (Fig. 19)．1\% Ponceau S 液にて味孔染色を行なっ た結果も，味孔部は無染で切断 5 日目々同様である.

光頭では, 切断側の上縦舌筋ならびに横舌筋の一部に みられる高度な萎縮像は正中部領域の非切断側まで及ん で認められる，系状乳頭の前面部角質首は厚みが減少 し，かつ後面部角質層とともに先端部に著しい剥䧹を呈 したものが多く認められる。また，本乳頭の先端は強く

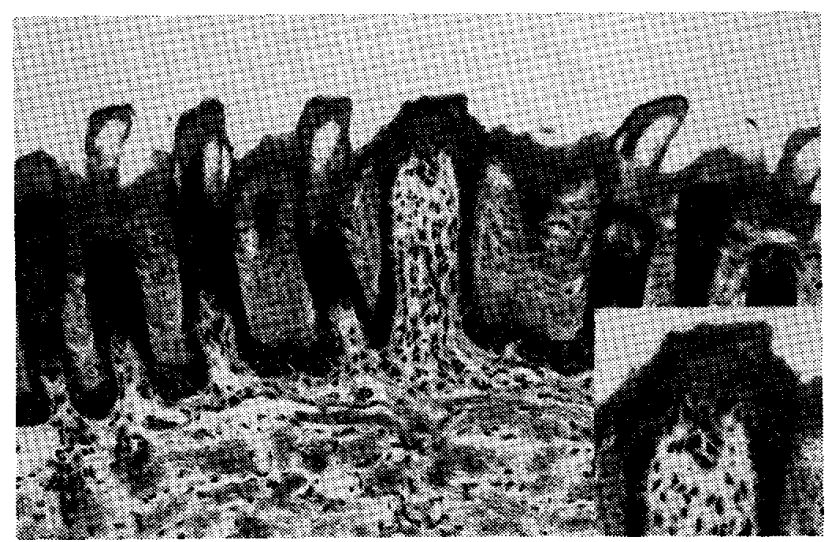

Fig. 21 切断 7 日目 咠状乳頭の断面像 $(\times 50)$

$$
\text { と一部拡大 }(\times 100) \quad \mathrm{H}-\mathrm{E} \text { 染色 }
$$

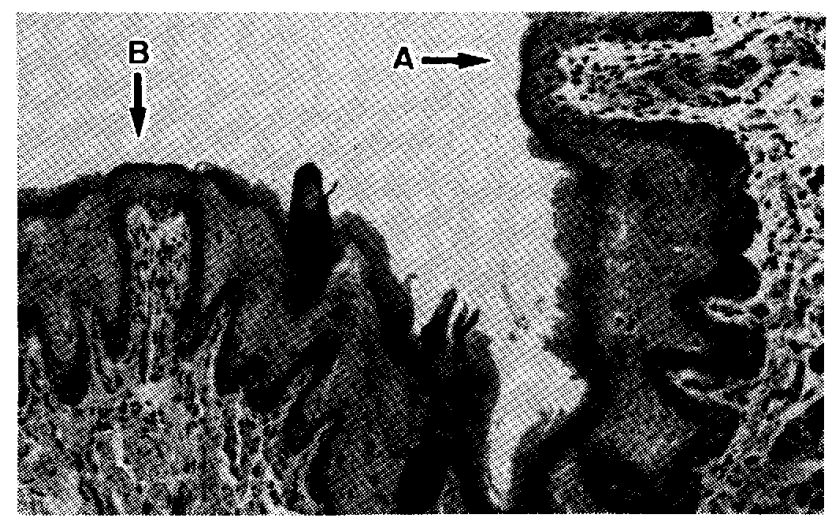

Fig. 22 切断 7 日目 正中寄りの节状乳頭の断面像 $(\times 50) \quad$ H-E 染色
A：非切断側
B：切断側 


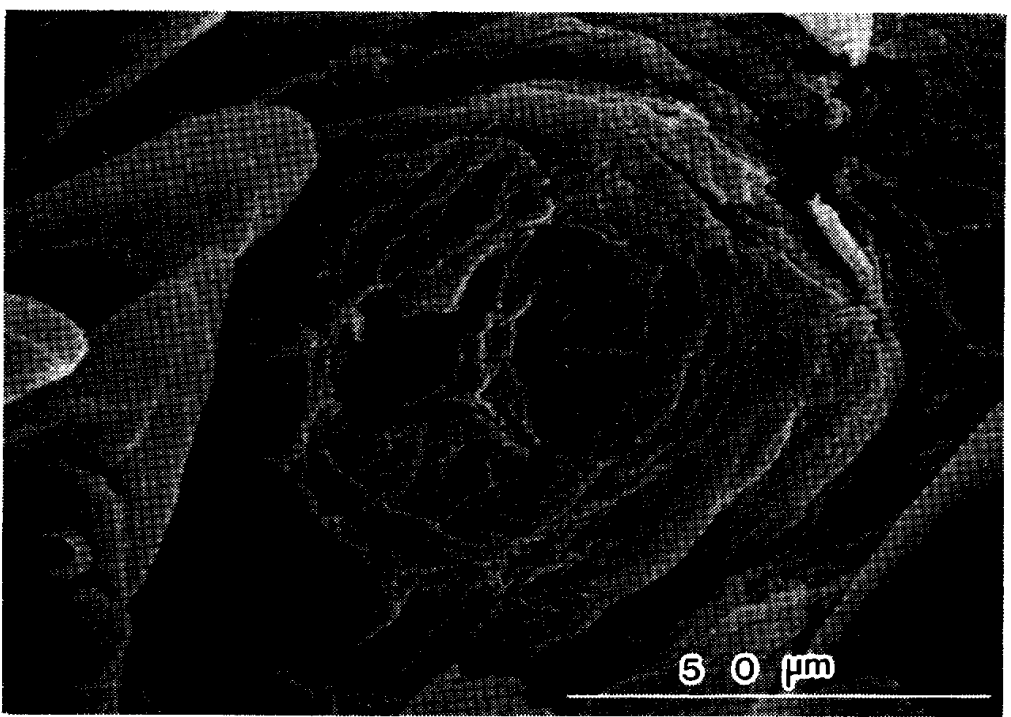

Fig. 23 切断10日目 革状乳頭の SEM 像

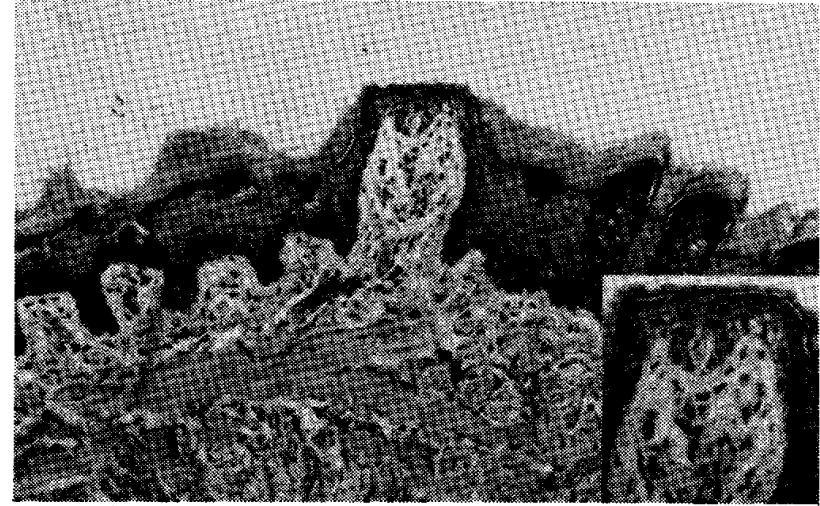

Fig. 24 切断10日目 咠状乳頭の断面像 ( $\times 50)$ と一部拡大 $(\times 100) \quad H-E$ 染色

窄され，同部の固有層の占める割合が非常に小さくなっ ている.このように，変形した革状乳頭における味蕾に は構成細胞はもはや観察されず，周辺の上皮紐胞に置き 換えられている (Fig. 21)。一方，舌前方部正中寄り の茸状乳頭には，切断側でも味蕾に変性を認めないもの や，逆に非切断側の味蕾に変性を認めるものも観察され る (Fig . 22).

切断10日目

切断 7 日目之同様，舌尖部の彎曲偏位や潰場形成をみ るものが半数例に琹められた、潰瘍形成部の系状乳頭は 久如しておらず，丈の短い乳頭の集合体として認められ る.

SEM 観察では, 系状乳頭は非切断側に比べて配列は 不規則となり，乳頭の先端も細くなったものが多く認め られる，乳頭基底部の上皮鞘の永離はそれはど著明では ない。

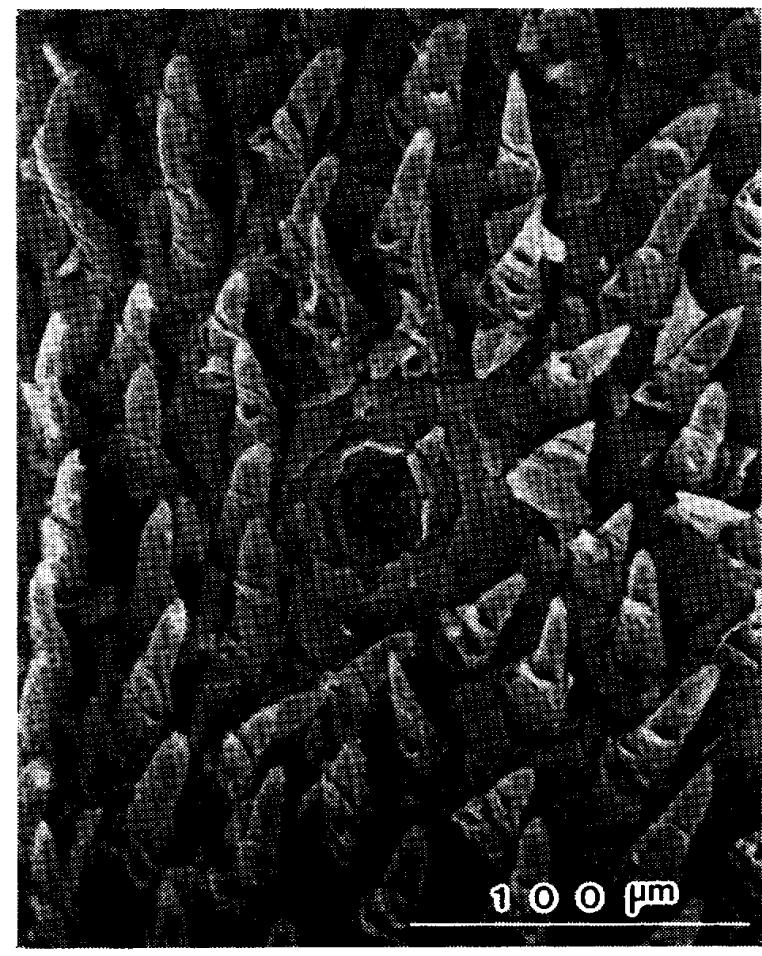

Fig. 25 切断14日目 糸状乳頭と茸状乳頭の SEM 像

苜状乳頭は切断 7 日目と同様，萎縮傾向が強く，乳頭 周壁上皮ならびに乳頭間粘膜上皮の剝離が著明である. また，乳頭背面中央部が陷凹したものや逆に隆起したも のなど形態的に一定せず，味孔の存在も諗められない (Fig. 23).

光顕で観察すると, 舌筋や糸状乳頭は切断 7 日目とほ ぼ同様な所見を呈している. 舌前方部の正中寄りの苗状 乳頭は, 形熊的に非切断側のものと大きな変化は認めら 


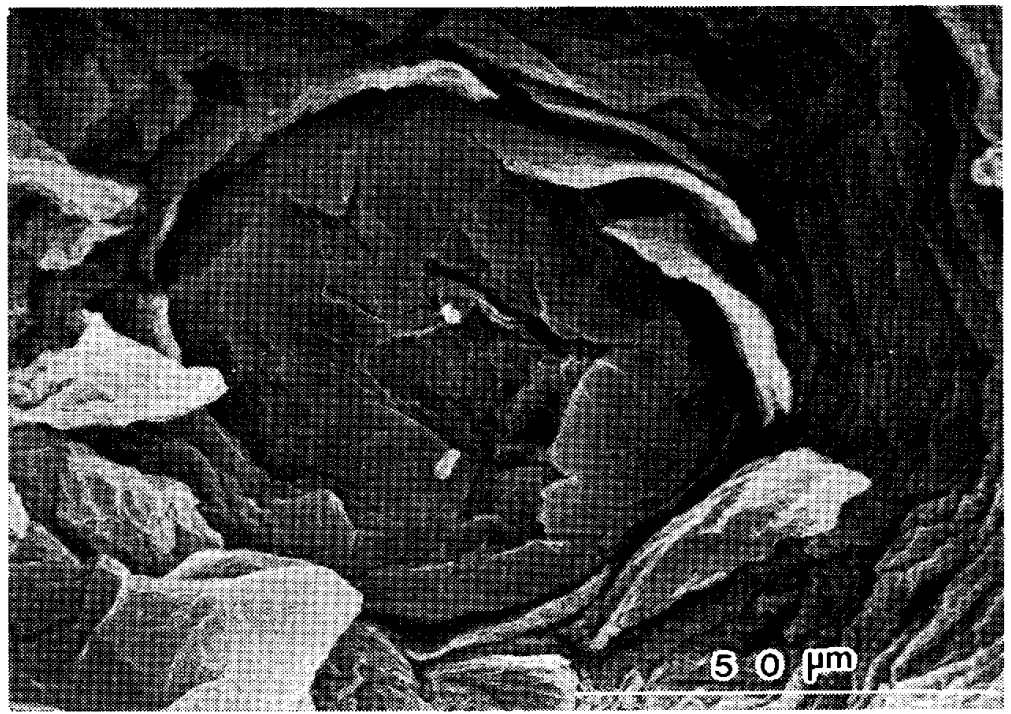

Fig. 26

切断14日目

茸状乳頭の SEM 像

れない，乳頭背面は平坦で，角質首も均質である。しか し，味蕾の幅径，丈とも減少し，味蕾本来の形態を有し ていない，味蕾中央部には周辺の上皮細胞より大きくし かも形態的に明調細胞に類似した細胞を弪めるが，非常 に数が少ない（Fig. 24）。一方, 舌中央部および側縁部 の莓状乳頭は著しく幅径が減少し，特に乳頭背面部にそ の傾向が顕著で，側面観が丸みを帯びたものが多く喼め られる，味蕾も幅径，丈とも減少し，円形を呈したもの が多い，味蕾構成細胞は，舌前方部の正中寄りのものと 同様な所見を呈するが，一部変性燷死したと思われる細 胞や完全に周辺の上皮細胞に置き換えられているものも あり多様な変化を示している。

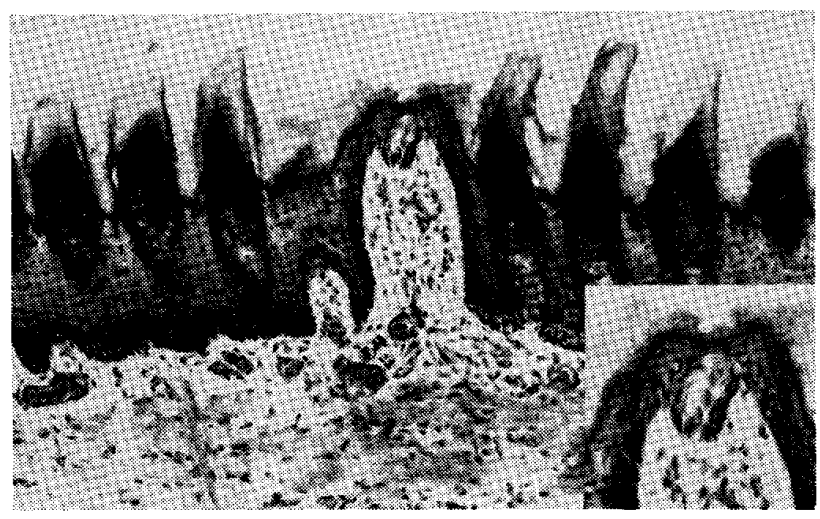

Fig. 27 切断14日目 茸状乳頭の断面像 $(\times 50)$ と一部抾大 $(\times 100) \quad \mathrm{H}-\mathrm{E}$ 染色

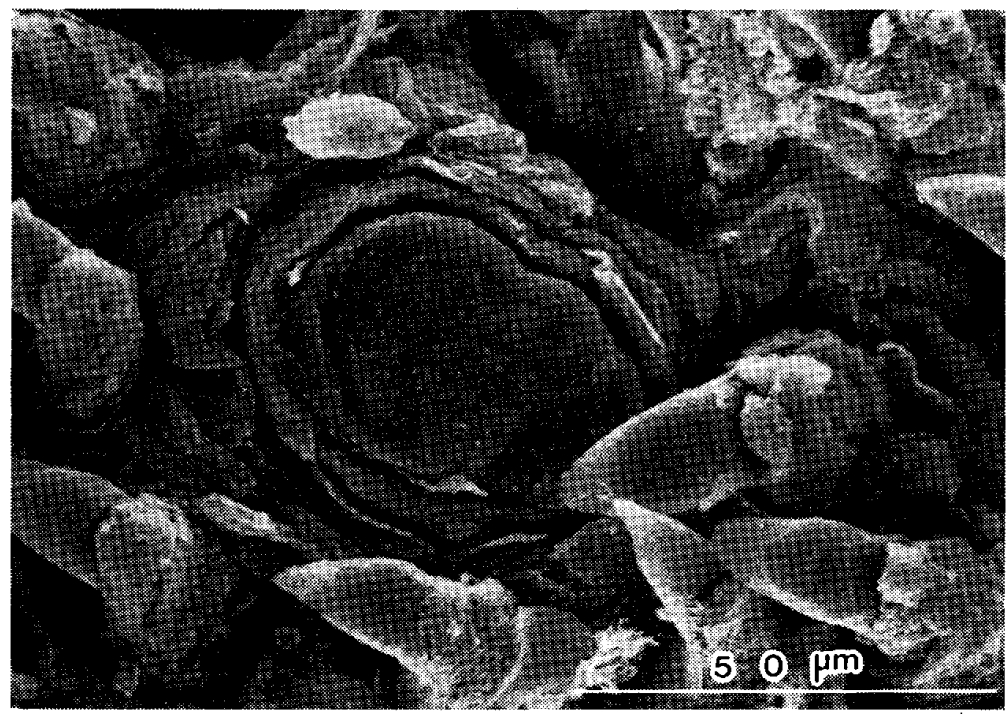

Fig. 28 切断21日目 茸状乳頭の SEM 像 


\section{切断14日目}

切断10日目之同様，舌尖が非切断側入彎曲偏位してい るものが多く珰められた。切断側舌尖部や側縁部の一部 に丈の短い糸状乳頭群が 6 例中 2 例観察されたが，前期 例までのものと比べて顕著ではない。

SEM で観察すると, 系状乳頭の配列は不規則で, 先 端がかなり先細りになったものも涩められるが, 前期例 までのものほど著明ではない（Fig.25).

茸状乳頭は萎縮して小さくなり，乳頭周壁上皮や乳頭 間粘膜上皮の剝離が著明となっている.乳頭背面は平坦 となっているものも散見される. 舌前方部の正中寄りの 乳頭中には，その背面中央部に味孔の開口を思わせるも

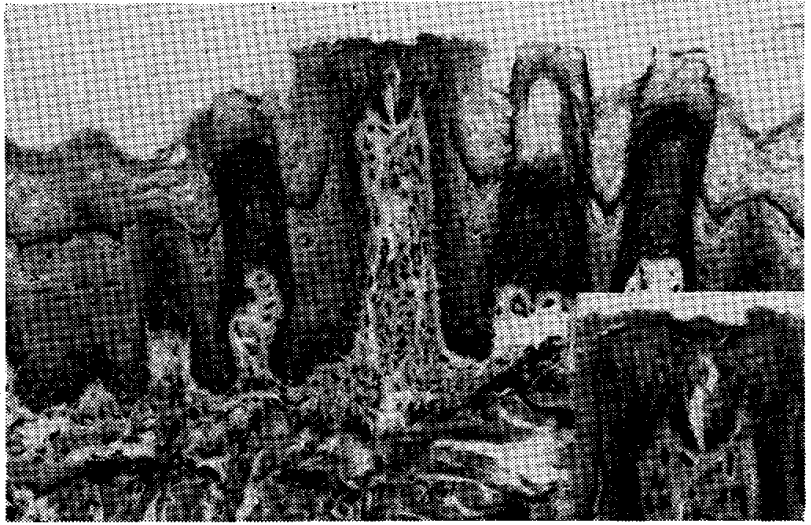

Fig. 29 切断21日目 咠状乳頭の断面像 $(\times 50)$ と一部桩大 $(\times 100) \quad H-E$ 染色

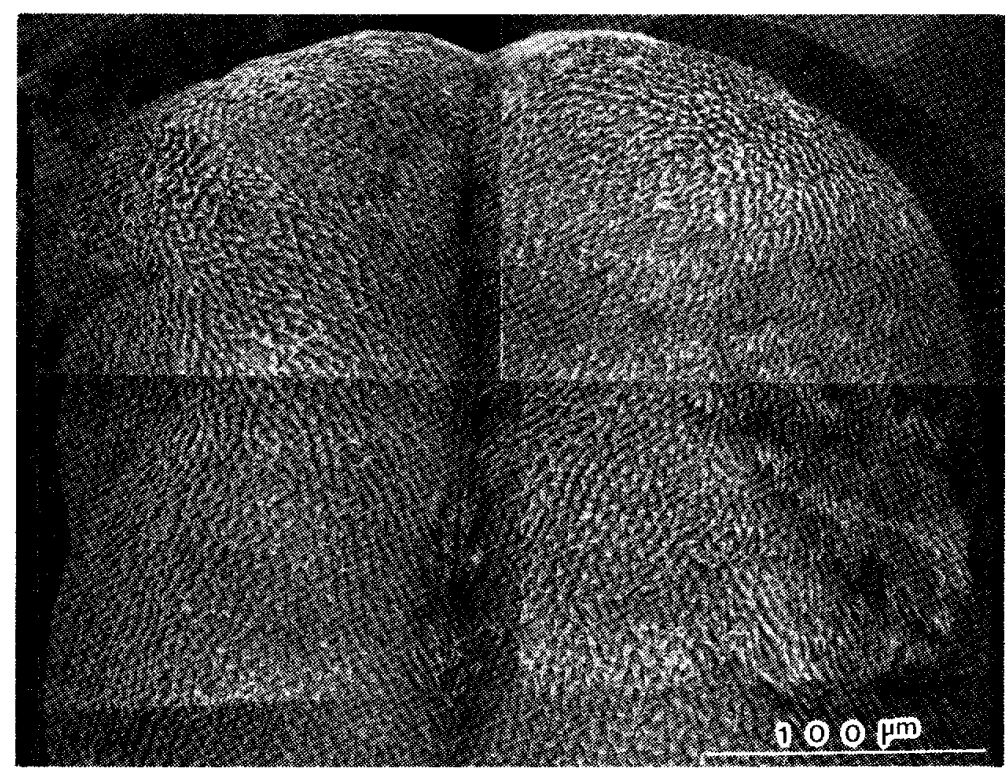

Fig. 30 切断 28 日目 SEM 像

のが存在するが, 味孔本来の形態を有していない（Fig . 26) .

糸状乳頭の組織構造は切断10日目とほとんど変わりな い. 革状乳頭は部位によりその変化の程度が異なってい る. 舌前方部の正中寄りのものは形態的変化が注とんど 諗められず，味蕾も非切断側のものと差異はみられな い，舌中央部ならびに側縁部の茸状乳頭は幅径が減少 し，乳頭背面において特に著明となっている．味蓄は変 性消失しているものや幅径が減少し長楕円形を呈してい るものなど多様な形態をしている。しかし，存在する味 蕾には非切断側にみられる明調細胞に類似した類円形の 大きな核を有する細胞や長紡錘形を呈したへマトキシリ ンに濃染する細胞が認められる（Fig.27）。

切断21日目

舌尖が非切断側入彎曲偏位しているものが 1 例のみ認
められた・しかし，前期例までに出現した舌乳頭の欠如 や丈の短い集合体は認められない。

SEM 観察による糸状乳頭の配列および形態等は非切 断側のものとほぼ同じように観察される。

茸状乳頭は，幅径はまだ小さいが乳頭背面は平坦にな っている.しかし，乳頭周壁上皮や乳頭間粘膜上皮には 依然として剥離を認め，乳頭背面上皮との境界が明瞭と なっている、味孔の開口はまだほとんどの乳頭に信めら れない (Fig. 28).

光顕では，系状乳頭には著変は認められない。舌尖の 彎曲偏位を認めた例には舌筋の一部に萎縮を認めるが， その他の実験例では正常所見を呈している. 革状乳頭の 幅径は依然として減少しているものの形態的には正常に 近くなっている. 味蕾の幅径もわずかに減少し長楕円形 を呈している．味蕾内には明調な類円形を呈した大きな 


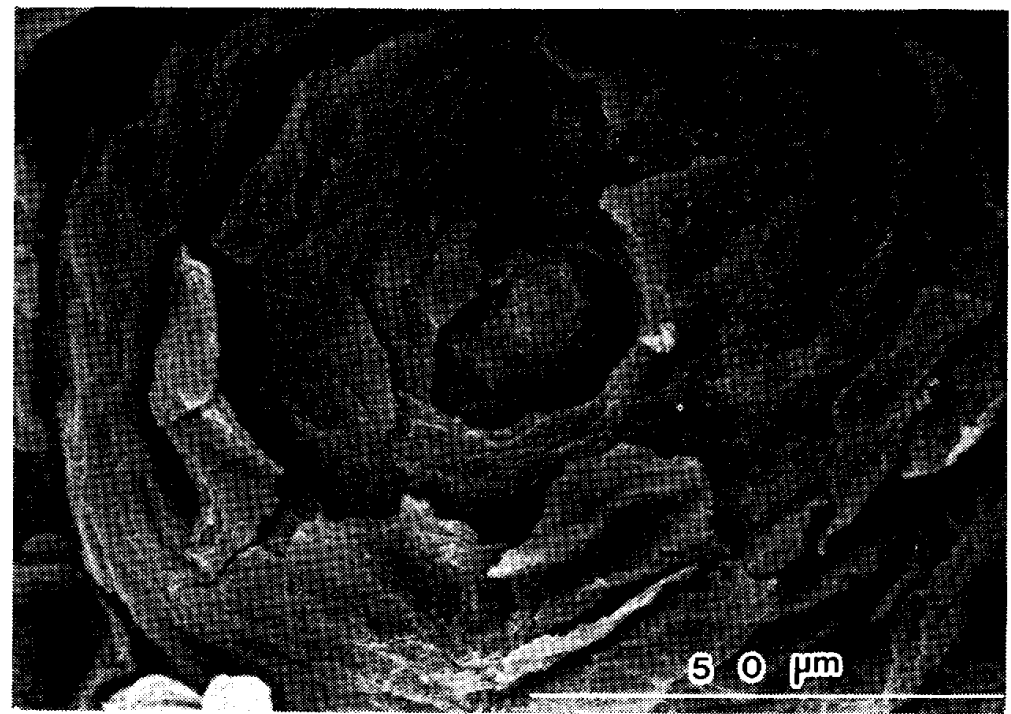

Fig. 31

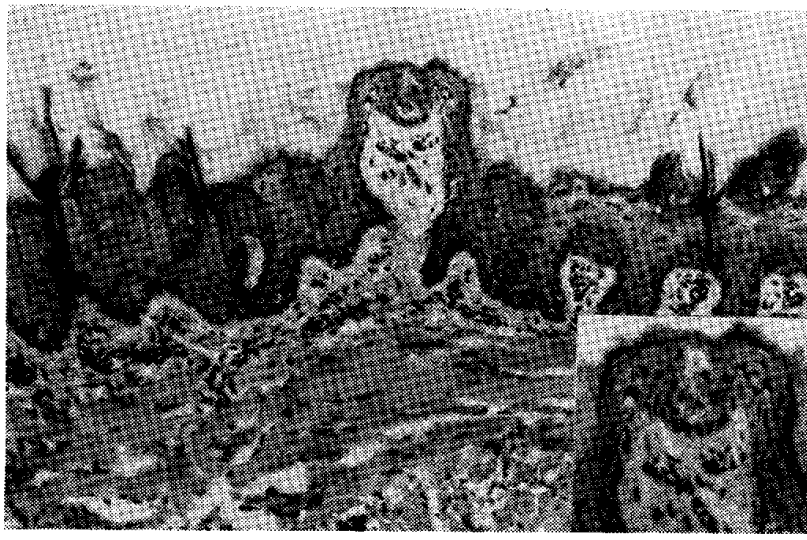

Fig. 32 切断28日目 咠状乳頭の断面像 $(\times 50)$ 乙一部搪大 $(\times 100) \quad H-E$ 染色

核を有する細胞やへマトキシリンに懐染する長紡鍾形を 呈した細胞が認められる。つまり，本期例では細胞質や 核の形態，染色態度など非切断側の味蕾構成細胞と類似 した細胞が多数観察されるようになる（Fig. 29）。 切断28日目

正中線に沿う舌正中溝に相当する部の彎曲偏位や舌 乳頭の変態像は全実験例においてもはや観察されない (Fig. 30).

SEM 観察では, 系状乳頭は切断21日目と同じ配列を 呈しておうり，形態も非切断側と差異を認めない。

革状乳頭は，幅径が幾分減少しているものの低倍にて たやすく確認できるようになっている．形態的にも切断 21日目之同様, 乳頭背面は平坦になっているものが散見 され，非切断側のものと差異を認めない，また，乳頭背 面中央部が陥凹し，味孔の開口を思わせる所見を呈する ものも多く諗められる。しかし，味孔本来の形態を有し
革状乳頭の SEM 像

ておらず，阴平上皮にて媜塞されている（Fig．31）。 光顕では，舌筋や系状乳頭には著変は認められない， 苗状乳頭の形態は非切断側茸状乳頭とほとんど差異を認 めない，味蕾は卵円形を呈したものが多く，非切断側 にみられる明調細胞ならびに暗調細胞に形態や染色態度 が酷似した細胞が周辺の上皮細胞と明瞭に区別できる (Fig. 32).

切断35日目

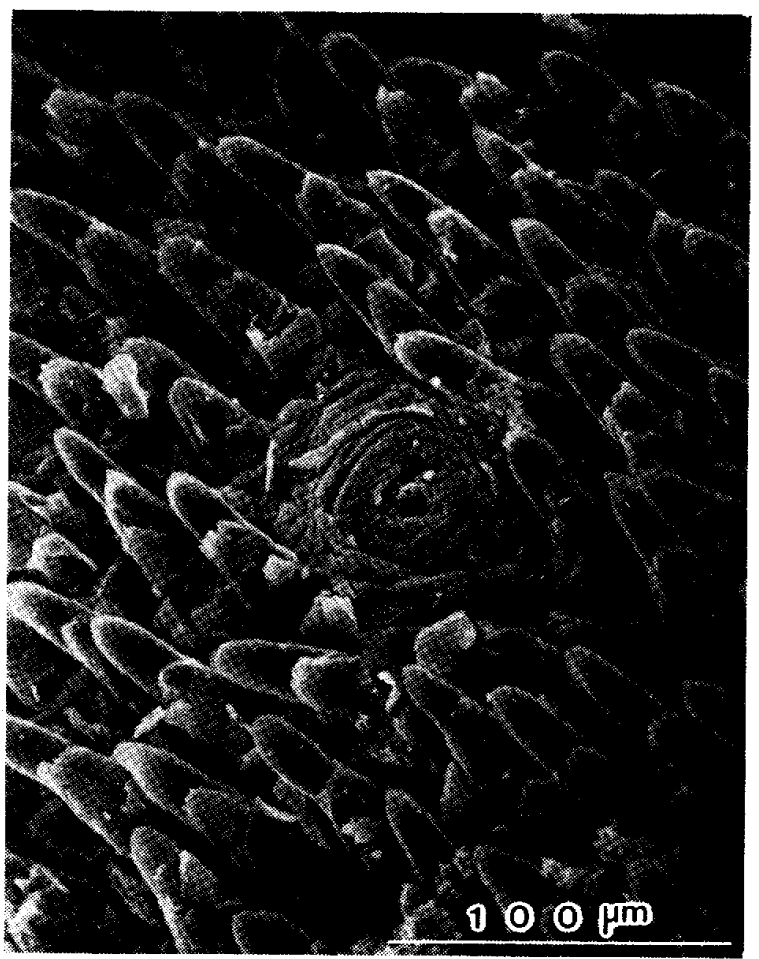

Fig. 33 切断35日目 系状乳頭と茸状乳頭の SEM 像 


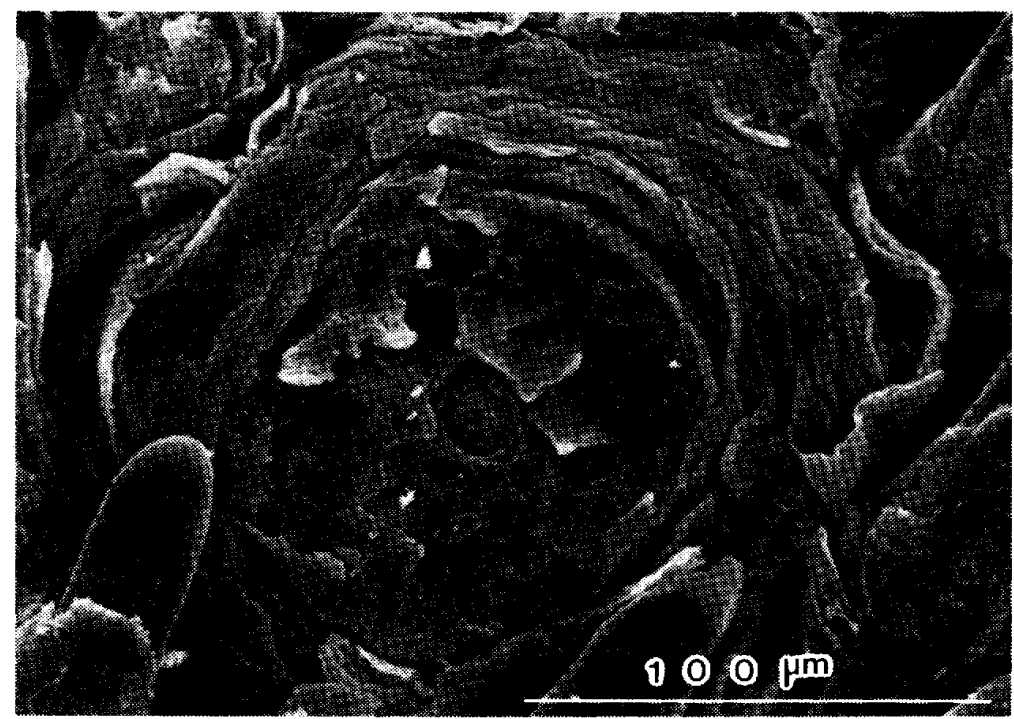

Fig. 34 切断35日目

苜状乳頭の SEM 像

切断28日目と同様，舌尖の彎曲偏位や舌乳頭の変態像 は全く認められない。

SEM 観察では, 系状乳頭は先端が丸みをもって前後 方向に重なりあい，配列ならびに形態において非切断側 のものと差異は認められない（Fig． 33）.

咠状乳頭は, 非切断側のものと同様な形態と幅径を呈 している. 乳頭背面は帯円形を呈し, 表面は一部上皮の 剝離を認めるが平坦さを増している。また，乳頭背面中 央部はやや陷凹して臍状ないし噴火口状の味孔の開口を 認める (Fig. 34) .

光顕でも舌筋や系状乳頭には変化は認められない，茸 状乳頭においても，乳頭背面は平坦で角質層も均質な厚 さを呈し，非切断側のものと差異を認めない，味蕾は畉

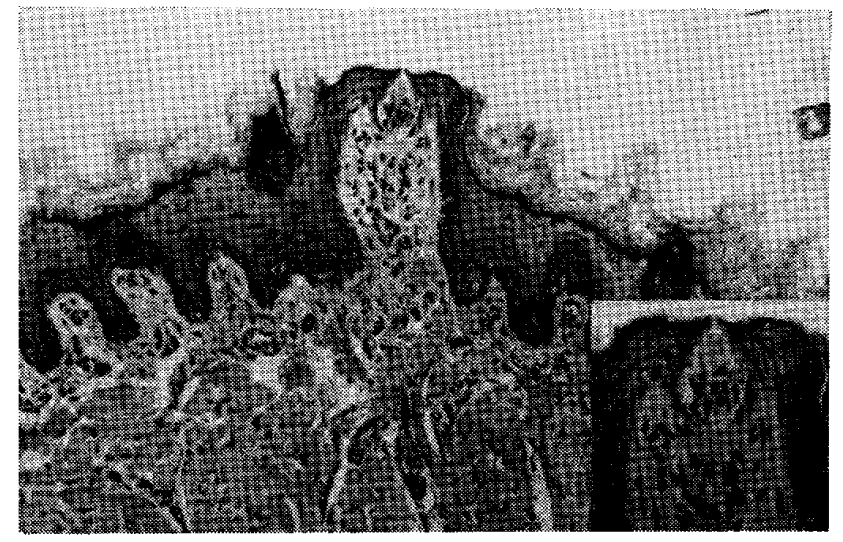

Fig. 35 切断35日目 咠状乳頭の断面像（×50） と一部拡大 $(\times 100) \quad H-E$ 染色

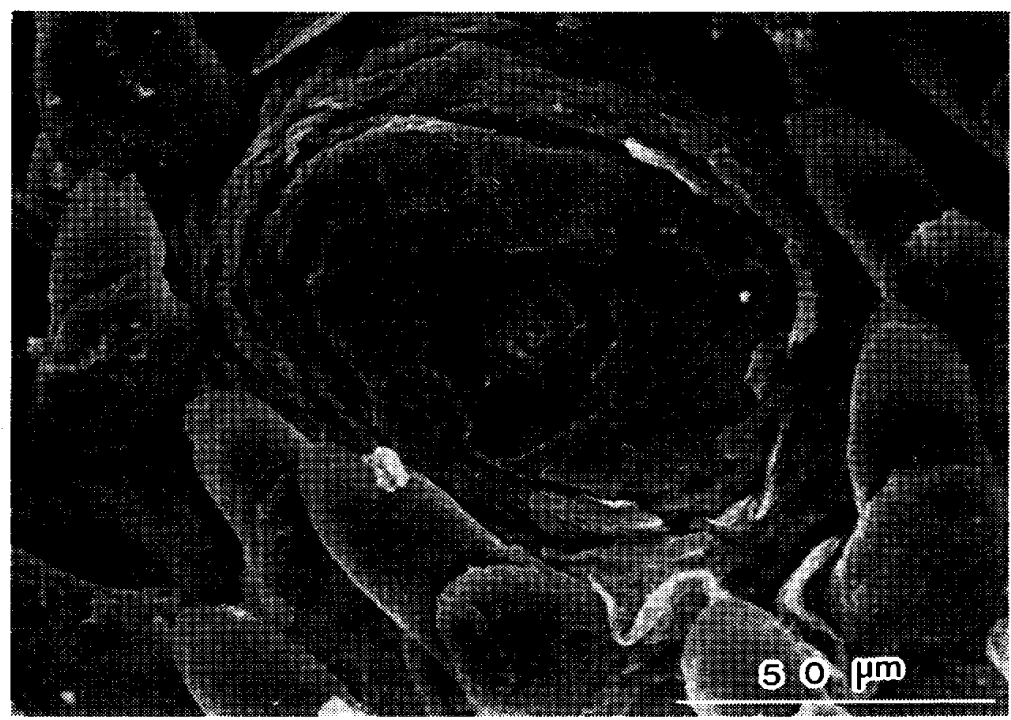

Fig. 36 切断60日目茸状乳頭の SEM 像 


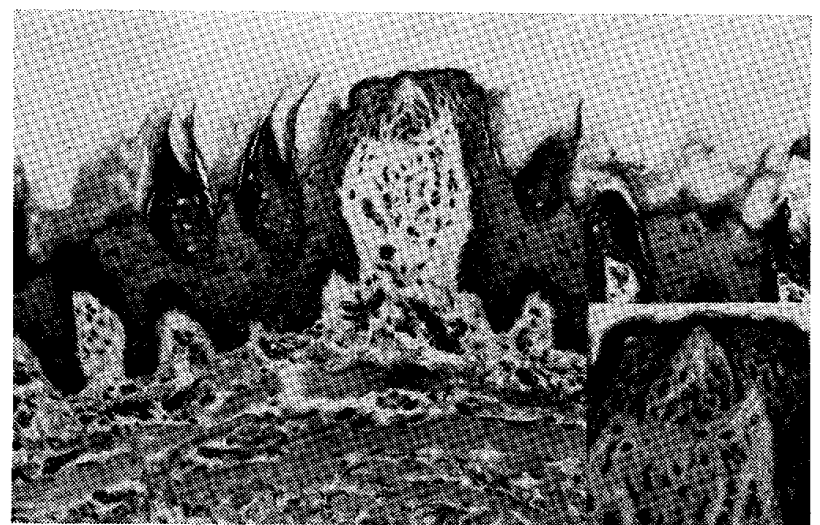

Fig. 37 切断60日目 苗状乳頭の断面像 $(\times 50)$ と一部拡大 $(\times 100) \quad \mathrm{H}-\mathrm{E}$ 染色

円形を呈し, 非切断側にみられる味蕾構成細胞と全く同 ビ特徴を有する細胞がすべての茸状乳頭味蕾に認められ る (Fig. 35).

以後の実験期日 $40,60 ， 90 ， 120$ 日の各例において 切断35日目所見と著変はみられず, 各乳頭とも完全な正 常像を呈する (Fig. 36,37).

\section{総括ならびに考察}

哺乳動物の舌には糸状乳頭, 茸状乳頭, 葉状乳頭およ び有郭乳頭といった形態の異なる乳頭が存在する，てれ らの各乳頭は動物によって多様な形態と分布の違いを示 すととがよく知られている．最近は SEM による各乳頭 の微細構造の研究も盛んに行なわれ, 特にケッ歯目につ いての研究報告が多くなされている22-32)。系状乳頭以 外の乳頭はすべて味蕾を含むので味覚乳頭と呼ばれてい るが, これらに分布する味覚神経を切断すると, 味蕾は 変性消失し, 一定期間を経過して神経が再生してくる と味蕾ももとの位置に再生することが報告されている1ー 17). 一般に神経はインパルスを伝導するのが仕事であ るが，それ以外に支配領域の細胞や組織の形態と機能を 維持させるための trophic function も有するといわれ ている・Torrey（1934）12)はナマズの味蕾と神経の関 係について “neurohumoral theory” を提議し, 味蕾 に対する神経の trophic function を説明した.また， Guth（1969）18)は味蕾の構造や機能維持のほか、，筋 線維の構造, 機能を完全に維持するのも神経の trophic function によるものであると述べている。てれらの ことから, 舌乳頭自体の形態と機能維持も分布神経の trophic function によることが十分想定される. 本研 究はそれらの事柄を実験的に確諮するためのものであっ たが，結果的には予想外の知見も得られたように思われ る. 所茪の総括, 考察に先立って, まず, 舌神経切断に
よって最も影響をうける舌体部の糸状乳頭と咠状乳頭の 正常構造に若干言及してみることにする。

ラットの糸状乳頭は, 舌の部位により形態を異にして いる. Kutuzov ら (1951)。 ${ }^{33}$ によると, ラット糸状乳 頭は舌尖から舌体後部にかけて形態の異なる 3 種の乳頭 (simple conical papillae, giant conical papillae, true filiform papillae) に区別されている.とのよう な変化のほとんどは食性の違いによるものと, 古くから Oppel (1900） 34）の成書や Sonntag $\left(1920^{35)}, 1925\right.$ 36') の総説で述べられている. Bradley (1971) 37)， 吉岡ら $(1975)^{24 \prime}$, 平山ら $(1984)^{38}$ はそれぞれラット の系状乳頭を SEM で観察しているが, 著者の観察所見 でも舌の部位による形態差をはっきりと確認することが できた。

系状乳頭を組織学的に観察してみると, 上皮層は構造 上の若干の相違から乳頭前面部, 乳頭後面部求よび乳頭 間部とに区別するととができる，各部上皮層の角化度 は後面部, 前面部, 乳頭間部という順に弱くなってい る.乙の上皮層の角化については，黼野 $(1967)^{391}$ や Farbman (1970 40) らが透過電顕で詳細に観察してい る.一般的に, 舌前方 $2 / 3$ は機械的外力にさらされる部位 である．そのため，乙の部の乳頭前面部上皮は厚い角質 層を有していると考えられる。

茸状乳頭は系状乳頭間に散在し，特に舌尖部に多く分 布している、乳頭の形態としては帯円形を呈しており, 乳頭背面は平坦で中央部には他の動物と同じように味 孔が通常 1 個認められる。味蕾を構成する細胞は主に $\mathrm{H}-\mathrm{E}$ 染色に淡染性の明調細胞と濃染性の暗調細胞に区 別され，乙れらの細胞は周りの上皮基底細胞汃ら分化し たものと考えられている41.

本実験での一番の変化所見は舌尖部の非切断側への彎 曲偏位であろう。切断 1 日目にして 1 例認め，3 日目以 降では央験例の半数に及んだ。著者が啮編した限りで は，舌神経切断による舌尖部の彎曲偏位を観察した報告 は見当らない．臨床的に，舌尖部の偏位をきたすものに 舌下神経麻瘦がある. 手術時の神経切断等によって起こ る純運動性の麻瘦で, 舌を前方に出すときに舌尖を箵患 側に彎曲偏位させる ${ }^{42)}$ 。逆に舌を引き込ませる時には， 舌尖は口中で健康側に偏り，舌が口腔底に休息した場合 においても舌の正中線はむしろ健康側に引かれるといわ れている43)，本実験の場合は，安静位の状態で舌下神 経麻㾇に類似した舌尖部の彎曲偏位を認めた。光顕的 に, 舌失部の上縦舌筋と横舌筋線維の一部に高度な姜縮 像が㒛められた。しかも，萎縮筋線維は正中を越えて非 
切断側にまで及んでいるという注目すべき所見を得た． Mizuno ら (1973) ${ }^{191}$ はネコの舌下神経切断実験を試 み, 術後 3 週目に舌筋に高度な萎縮を認め, 舌粘膜その ものには 4 週間を経ても変化はみられなかったと述べて いる. 光顕でも, 舌下神経切断例と似た様な萎縮像を観 察したととになるが，術式で示したごとく，舌神経の切 断に際し手術用顕微鏡を使用し，神経，血管の損傷には 細心の注意を払っているため舌下神経を直接切断するよ うなととはあり得ない。したがって，舌神経のどてかに 舌下神経との交通枝が存在し，その交通枝を舌神経とと もに切断したため舌下神経麻疾時と同様な変化が生じた とも考えられる，一部の成書には，“舌下神経は舌骨舌 筋外面で舌神経と交通する上方に向から枝が存在する” と記載されている44)。しかし，まだその交通枝が一般 的に確認されていないため今後の検討すべき課題であ る、また，舌は口腔内の種々の部位，特に舌自身の接触 などの感覚によって運動を調節していると考えられてい るが, 舌神経の切断によっててれらの感覚が消失し, 舌 の運動や緊張に変化が生したととも十分に推測される。

さらに, ラットの舌前方部筋には筋紡錘が存在すること が報告されている45ー47)。乙の筋紡錘は，筋の伸張の程 度を中枢に伝達する機能を有しており，舌神経の切断に よって筋紡錘からの情報が消失するため舌筋の収縮の平 衡に乱れが生じたとも考えられる。またさらには，舌 神経が舌の主たる栄養神経であることから，前述した neurotrophic な影響も推測するてとができる.以上， 本実験にみられた舌尖部の彎曲偏位について考えられる 要因を述へててきたが，著者の実験方法ならびに観察方法 からはこれらのどの要因によるかは一概に断定すること はできない.しかし，本実験を通じて，舌神経が舌筋の 機能に何らかの関係があるてとが示唆される.

本実験における二番目の変化としては，切断 3 日目か ら舌尖部の彎曲偏位例の舌尖部系状乳頭の不規則配列と 乳頭先端の尖鋭化傾向が現われることである.このよう な舌尖部の彎曲偏位に伴う系状乳頭の変化は舌神経切断 によって生じた舌の咀嚼関与の変化，あるいは栄養神経 としての機能の消失によるものと考えられる.

同じく切断 3 日目からの変化としては, 舌尖部や側緣 部に分布する系状乳頭と茸状乳頭の一部の欠如と，その 部における潰瘍形成があげられる，北村 $(1965)^{7}$ はラ ット舌咽神経切断後 9 日目の 1 例に潰瘍形成を認めてい る. Mizuno ら (1973) ${ }^{19}$ はネコ舌神経切断後早期より 舌尖と舌縁に乳頭脱落と上皮剶離を認め，乙れらの変化 は急速に進展し, 術後 48 時間以内に潰場形成を諮めたと
報告している．本実験が舌の知覚を支配する舌神経の切 断であることから舌の知覚麻㾝が主たる要因となって， Mizuno ら (1973) 19) も指摘するごとく機械的刺激を受 けやすい舌尖および側縁部に潰瘍を生じたものと考えら 机る。

次の変化としては，咠状乳頭と味蕾の変化が切断 3 日 目からはじまることである．北村（1965） 7) はラット舌 咽神経を切断すると，切断後 2 日目頃より有郭乳頭とそ の味蕾が萎縮していくととを述べている．また，石井 (1979) ${ }^{20}$ 怕七トにおける鼓索神経切断による茸状乳頭 の変化を観察し，切断後 1 年を経てから乳頭の数の減少 や逐年的な退行性変化を起てすと述べている．本実験で は, 舌神経切断後早期より茸状乳頭の背面上皮の樎凹と 周壁上皮の剥離傾向を認めた。乙のように，本実験を含 めた舌神経や舌咽神経切断による舌粘膜の変化は，鼓索 神経のみの切断と異なり乳頭自体の変化が早く出現して いるようである.とのととは，舌体部の知覚神経である 舌神経が舌粘膜の機能の維持のみでなく, 形態の維持に も重要な㗢きをなしているものと考えられる。

Guth (1958) ${ }^{48)}$ や State（1977） ${ }^{49)}$ は切断した舌咽 神経の末梢端に舌下神経を吻合した場合，味蕾は再生し ないということを実験的に立証している。このことは， 舌咽神経や舌神経に含まれる味神経線維のみが特定領域 の上皮基底細胞を味蕾細胞に分化させ，運動神経注全く 関与し得ないととを明確にしたものである．Guth（19 $57)^{51}$ はラッ卜舌咽神経を切断し, 術後 3 日目上り味蕾 細胞は急速に減少しはじめ, 術後 7 日目までに味蕾は完 全に消失して扁平上皮にて置換されると述へている．ま た，北村 $(1965)^{7)}$ は舌咽神経切断後24時間までは形熊 的には正常味蕾と変わらず，術後 5 日目になると味蕾 の下方に新しい上皮基底細胞が形成されると報告してい る. Fu jimoto ら $(1970)^{10}{ }^{0}$ はウサギの舌咽神経を神経 節下部で切断し, 有郭乳頭味蕾の変性と再生の過程を透 過電顕によって詳細に観察している。それによると，神 経切断12時間後から 2 日目にかけ味蕾細胞は変性しはじ め, まず第 3 型細胞の変性過程が顕著に現われ，次いで 第 2 型細胞が同様の変化をはじめる.さらに，2 日目以 降各型は自己融解を示すが，第 1 型細胞が他型の壊死細 胞や変性産物克責食し，切断10日自には味蕾は乳頭上 皮組織からほとんど消失すると報告している，近藤（19 83) ${ }^{50)}$ もマウス舌咽神経切断実験で，Fu jimoto ら（19 70) 101 と同様な結果を得ている.

本実験の場合，切断 1 日目では味蕾および味蕾構成細 胞は非切断側と同様な所見を呈するが， 3 日目より味蕾 
構成細胞，特に明調細胞の数の減少を認めるようになっ た. 切断 5 日目では, 幅径, 丈ともに減少した変性味蕾 を認め, 味蕾構成細胞に㧍いても明調細胞はもはや観察 されなかった．切断 7 日目になると，味蕾はすべて完全 に変性消失し，周辺の上皮細胞に置換されていた，以上 のように，著者の実験結果はこれまでのラットに扑ける 報告とほぼ同様で, 舌神経ないし舌咽神経を切断しても 味蕾の変性速度に差は認められない。

また，本実験では変性過程にある切断 3 日， 5 日， 7 日目の経日において味孔染色を試みた。味孔を特異的に 染色する方法は Brouwer ら (1978) 211 によってサル やラットの舌乳頭を用いた報告がある。乙の方法は味孔 内の粘液多糖を特異的に染色し，味孔の識別を容易に行

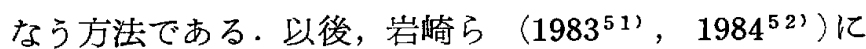
よりイヌ，モルモットの舌乳頭において追試され，その 有用性が確認されている。しかし，本実験のような神経 切断実験に応用したものはない，本実験の場合，特に切 断 3 日目の SEM 観察ですべての茸状乳頭に味孔の開口 が認められたにもかかわらず，味孔染色を施すと味孔部 は全く色素に染まらず明らかに非切断側の味孔と区別さ れた。このととは, 変性過程にある茸状乳頭ならびに味 蕾において, 種々の刺激から味蕾細胞を保護する役目を もつ中性粘液多糖類は神経切断により全く分泌されてお らず，味蕾としての機能を欠いているてとを示すものと 思われる。

支配神経切断後における味蕾細胞再生の出現時期は, 動物種や研究者間で多少異なっている.ラットでは切断 後 23 日 $^{17}$ または 29 日以後 ${ }^{7}$, ウサギでは 25 日以後 ${ }^{101}$ と されている.最も早いのはマウスで神経切断後14日頃と いう近藤（1983）50' の舌咽神経切断による報告がある. 著者の場合, 切断21日目にほとんぞの切断側茸状乳頭上 皮首に再生味蕾細胞を観察した。一方，SEM 観察にお いても切断21日目より咠状乳頭背面が平坦となり乳頭の 再生を思わせる所見を認めたが，味孔は閉塞していた． 味孔には，味物質を受容する味毛（microvilli）が派生 しているが531， ラットにおける咠状乳頭味蕾の味孔の 径は小さく，しかも microvilli の先端が味孔から乫出 する例は極めて少ないとされている411。しかし，本実 験においてわずか1例ではあるが味管から味孔開口部に かけて microvilli と思われる構造物を認めた。このよ うに, 味孔は味覚感受機構を考える上で重要な位置を占 めており，本実験では神経切断 35 日目以降の全症例に閉 塞していた味孔の開口を琶めたてとから, 同時期におけ る革状乳頭の形態的ならびに構能的回復を推測するとと
ができる。

Guth $(1963)^{6}{ }^{6}$ は片側舌咽神経切断後のラット有郭乳 頭において，味蕾総数のわずか $12 \%$ \%消失したにすぎな いと述へている.乙れは, 残存する味蕾が両側的に神経 支配されることを意味しており，Hayes ら $(1942)^{54)}$ によって報告された両側神経支配説を暗に裹付けるもの である。

著者の実験においても, 片側舌神経切断後の舌尖部押 ょび正中寄りの部の乳頭ならびに味蕾において，変性・ 再生像を呈するものと最初から全く変化しない，つまり 正常像を呈するものが認められた。このてとは，舌尖部 や正中溝相当部付近は舌神経が錯走しているてとを意味 するものと考える。

\section{結}

\section{論}

舌神経の舌粘膜，特に舌乳頭の形態とその機能維持に 対する役割を追求するため，ラット片側舌神経を切断 し, 舌前方部の動態を病理組織学的ならびに走查電子顕 微鏡的に検索し，次のような結果を得た。

1. 舌神経切断 1 日目において, 舌尖部が非切断側に 彎曲偏位した 1 例を認めた。 以後, 切断 3 日目から14日 目までの各例のほとんどに彎曲偏位がみられ，乙の部分 の舌筋の一部に萎縮像が認められた。

2. 切断 3 日目より, 舌尖あるいは侧縁部の系状乳頭 の配列が不規則になるとともに，一部に乳頭の欠如を伴 った潰瘍形成がみられた。この変化は切断14日目まで継 続し，以後の経日においては認められなかった。

3. 切断 3 日目より, 茸状乳頭の味蕾細胞に変性像が 観察されるようになり，特に細胞数の減少が著明であっ た。

4. 切断 7 日目では, 味蕾はすべて完全に変性消失 し，周辺の上皮細胞に置換されていた. SEM で観察す ると，节状乳頭に強い萎縮が認められ，乳頭としての判 別が困難であった。

5. 切断21日目には, 茸状乳頭上皮層に味蕾の再生が 観察された。しかし，味孔の発育は十分でなく，外界と の交通はまだ認められなかった。味孔の開口は舌神経切 断35日目以降になって全実験例に喼められた。

6. 神経切断による舌尖部や舌正中部に分布する咠状 乳頭とその味蕾の変性・再生像は必ずしも切断側にみら れるものではなく，非切断側の一部にもみられた。ま た，切断側においても全く变化を受けない正常な乳頭も みられた。

以上の結果より, 舌神経は知覚および味蕾の再生・分 
化のみならず，舌粘膜の機能維持にも極めて重要な関わ りがあるとともに，さらには舌尖部の筋肉の運動にも何 らかの関係があることが示唆された。

稿を終るに臨み，終始御䅰篤なる御指導と御校閲を賜 った恩師九州曾科大学第 1 口腔外科学教室山田長敬教授 に深甚の謝意を捧げるとともに，御烈篤なる御助言と御 校閲を賜った福岡歯科大学口腔解剖学教室第 2 講座藤英
俊助教授に対し，叓心より感謝致します。

また本研究を遂行するにあたり，種々御協力戴きまし た教室員諸兄に御礼申し上げます.

本論文の要旨は，第43回九州䨑科学会総会（昭和58年 5 月 29 日），第 29 回日本口腔外科学会総会（昭和59年 9 月27日)，第45回九州歯科学会総会 (昭和60年 5 月 26 日) において発表した。

\section{引用 文 献}

1) Olmsted, J. M. D. : The results of cutting the cranial nerve in amiurus nebulosus. J. Exp. Zool. $311: 369-401,1920$.

2) Olmsted, J. M. D. : Effects of cutting the lingual nerve of the dog. J. Comp. Neurol. 33 : $149-154,1921$.

3) Olmsted, J. M. D. : Taste fibers and the chorda tympani nerve. J. Comp. Neurol. 34 : $337-341,1922$.

4 ）上野正康：味蕾の変性並びに再生に関する実験的研究. 九州荬会誌 $7: 19-43,1953$.

5 ) Guth, L. : The effects of glossopharyngeal nerve transection on the circumvallate papilla of the rat. Anat. Rec. $128: 715-731,1957$.

6) Guth, L. : Histological changes following partial denervation of the circumvallate papilla of the rat. Exp. Neurol. 8:336-346, 1963.

7 ) 北村勝也：味蕾の変性並びに再生に関する神経組織学的研究. 九州百会誌 $18: 1-40,1965$.

8 ) Farbman, A. I. : Fine structure of degenerating taste buds after denervation. $J$. Embryol. Exp. Morph. 22: 55-68, 1969.

9) Iwayama, T. : Changes in the cell population of taste buds during degeneration and regeneration of their sensory innervation. Z. Zellforsch $110: 487-495,1970$.

10) Fujimoto, S. and Murray, R. G. : Fine structure of degeneration and regeneration in denervated rabbit vallate taste buds. Anat. Rec. 168:393-414, 1970.

11) Zelewski, A. A. : Regeneration of taste buds after reinnervation of a denervated tongue papilla by a normally nongustatory nerve. J. Comp. Neurol. $200: 309-314,1981$.

12) Torrey, T. W. : The relation of taste buds to their nerve fibers. J. Comp. Neurol. $59: 203$ $-220,1934$.

13) Beidler, L. M. : A theory of taste stimulation. J. Gen. Physiol. 38:133-139, 1954.

14) Oakley, B. : Reformation of taste buds by crossed sensory neves in the rat's tongue. Acta Physiol. Scand. 79:88-94, 1970.

15) Cheal, M., Dickey, W. P., Jones, L. B. and Oakley, B. : Taste fiber responses during reinnervation of fungiform papillae. J. Comp. Neurol. 171:627-649, 1977.

16）古野秋生：カエル舌咽神経の再生に関する実験的研究.九州崡会誌 $30: 904-924,1977$.

17）井ノ上俊郎：ラット舌神経の再生に関する実験的研究. 九州歯会誌 $32: 282-297,1978$.

18) Guth, L. : "Trophic" effects of vertebrate neurons. Neuroscience Res. Bull. 7:1-73, 1969.

19) Mizuno, N., Akimoto, C., Mochizuki, K. and Matsushita, R. : Experimental studies of afferent fibers in the hypoglossal nerve in the cat. : A scanning electron microscopic observation on the lingual mucosa following transection of the nerve, and a degeneration study with silver impregnation methods. Arch. histol. jap. 35:99-113, 1973. 
20）石井泰平：ヒト茸状乳頭の生体顕微鏡学的研究 その 1 : 数, 形熊, 終末毛紼血管にみられる年龄変動と性 差について その 2 ：鼓䒺神経切断例における茸状乳頭の変化. 日耳鼻 $82: 271-281,1979$.

21) Brouwer, J. N. and Wiersma, A. : Location of taste buds in intact taste papillae by a selective staining method. Histochemistry $58: 145-151,1978$.

22) Shimamura, A., Tokunaga, J. and Toh, H. : Scanning electron microscopic observations on the taste pores and taste hairs in rabbit gustatory papillae. Arch. histol. jap. 34:5160,1972 .

23）武藤 浩：走查型電子顕微鏡による舌乳頭の角化上皮に関する研究. 愛知医大誌 $1: 162-165 ， 1973$.

24）吉岡郁夫・武藤 浩・尾関教生・大石みち子：ラットの個体および舌尖の部位による糸状乳頭の形態的差異. 愛知医大誌 $3: 216-220,1975$.

25）大石みち子・吉岡郁夫・武藤 浩：モルモット舌の表面構造：とくに糸状乳頭の局所的変異について. 愛知 医大誌 $4: 32-35,1976$.

26) Yoshioka, I. and Muto, H. : Surface structures of the tongue, palate and buccal mucosa of the rat (Scanning electron microscopic studies on the oral mucosa 3). Okajima's Fol. anat. jap. $52: 297-312,1976$.

27) Shimizu, T., Kusano, T. and Wada, M. : The fine structure of the papillary epithelium on the tongue of albino rats and albino mice. Zoological Magazine $88: 188-192,1979$.

28) Toyoshima, K. and Shimamura, A. : A scanning electron microscopic study of taste buds in the rabbit. Biomed. Res. 2 Suppl. 459-463, 1981.

29）藤田浄秀・木村 進・鈴木信治・小田島哲也・大谷隆俊：ハムスタ一舌背の形態学的研究一特に解剖名に関 して一。 日外誌 $28: 829-839,1982$.

30) 河野敏明：モルモット舌乳頭の形態ならびに有郭乳頭の発生学的研究. 九州歯会誌 37：1012-1027, 1983 .

31）岩崎信一・坂田公一・森 秀樹・上野瑞生子・小林 寛：走查電子顕微鏡によるシャコウネズミ（Suncus murinus) の舌背粘膜の微紲構造. 霜基礎誌 $25: 471-480,1983$.

32）岩崎信一・宮田 健・森 秀樹・坂田公一・小林 寛：ラット舌背表面の微細構造. 解剖誌 59：18一27， 1984 .

33) Kutuzov, H. and Sicher, H. :The filiform and conical papillae of the tongue in the white rat. Anat. Rec. 110:275-288, 1951.

34) Oppel, A. : Lehrbuch der vergleichenden mikroskopischen Anatomie der Wirbeltiere. Bd. 3, Gustav Fischer, Jena. 1900, 124-425.

35) Sonntag, C. F. : The comparative anatomy of the tongue of the mammalia. I. General description of the tongue. Proc. Zool. Soc. Lond. 1920, 115-129.

36) Sonntag, C. F. : The comparative anatomy of the tongue of the mammalia. XII. Summary, classification and phylogeny. Proc. Zool. Soc. Lond. 1925, 701-762.

37) Bradley, R. M. : Tongue topography. In : Handbook of sensory physiology. 4. Chemical senses (ed. by Beidler, L. M.). Springer-Verlag, Berlin, Heidelberg, and New York, 1971, $1-30$.

38）平山明彦・宮本時男・小林一公・坂井 剛・佐藤 靖・高橋博水・多胡 森・見明 清：ラット舌糸状乳頭 の発育に伴なう形態変化に関する研究. 䨑科学報 $83: 1667-1677,1984$.

39）雪野莞爾：ラッテ舌粘膜上皮の微細構造と角化について．札幌医誌 $31: 243-271,1967$.

40) Farbman, A. I. : The dual pattern of keratinization in filiform papillae on rat tongue. $J$. Anat. $106: 233-242,1970$.

41) Farbman, A. I. : Fine structure of the taste bud. J. Ultrast. Res. $12: 328-350,1965$.

42）深谷昌彦・山田長敬・岡野博郎・古本克磨・待田順治・工藤逸郎：口腔外科診断学. 書林，東京，1983， 
314 .

43）平山恵造：神経症候学. 文光堂, 東京, 1971，253-255.

44）上條雍彦：口腔解剖学 第 4 巻 神経学.アナトーム社，東京，1981，964.

45) Langworthy, O. R. : A study of the innervation of the tongue musculature with particular reference to the proprioceptive mechanism. J. Comp. Neurol. 36:273-297, 1923.

46) Barron, D. H. : A note on the course of the proprioceptor fibres from the tongue. Anat. Rec. $66: 11-15,1936$.

47）浜野 信：舌に分布する神経の組織学的研究. 京府医大誌 $70: 2119-2124,1961$.

48) Guth, L. : Taste buds on the cat's circumvallate papilla after reinnervation by glossopharyngeal, vagus, and hypoglossal nerves. Anat. Rec. 130:25-37, 1958.

49) State, F. A. : Circumvallate papilla of dog following suture of the hypoglossal and glossopharyngeal nerves. Acta Anat. $98: 413-419,1977$.

50）近藤 功：マウスの変性および再生味蕾の組織化学的研究一特にモノアミン前駆物質の取り込みについて一。 歯基礎誌 $25: 745-762 ， 1983$.

51）岩崎 正・豊島邦昭・捣村昭辰：味孔染色法による味蕾の分布に関する研究一第 1 報一[会]，九州歯会誌 $37: 832,1983$.

52）岩崎 正・下田妙子・嶋村昭辰：味孔染色法による味蕾の分布に関する研究一第 2 報一〔会】. 九州雨会誌 $38: 778-779,1984$

53）富山紘彦・池田 稔・松山 仁・富田 寬：味孔の微細形態的観察と $2 ， 3$ の知見，日耳鼻 82：178一185, 1980 .

54) Hayes, E. R. and Elliotto, R. : Distribution of the taste buds on the tongue of the kitten, with particular reference to those innervated by the chorda tympani branch of the facial nerve. J. Comp. Neurol. $76: 227-238,1942$. 